\title{
Low-resolution Australasian palaeoclimate records of the last 2000 years
}

\author{
Bronwyn C. Dixon ${ }^{1}$, Jonathan J. Tyler ${ }^{2}$, Andrew M. Lorrey ${ }^{3}$, Ian D. Goodwin ${ }^{4}$, Joëlle Gergis ${ }^{5}$, and \\ Russell N. Drysdale ${ }^{1}$ \\ ${ }^{1}$ School of Geography, University of Melbourne, Melbourne, 3010, Australia \\ ${ }^{2}$ Department of Earth Sciences, University of Adelaide, Adelaide, 5005, Australia \\ ${ }^{3}$ National Institute of Water and Atmospheric Research, Auckland, 1010, New Zealand \\ ${ }^{4}$ Marine Climate Risk Group and Department of Environmental Sciences, Macquarie University, \\ Sydney, 2109, Australia \\ ${ }^{5}$ School of Earth Sciences, University of Melbourne, Melbourne, 3010, Australia
}

Correspondence to: Bronwyn C. Dixon (bdixon1@student.unimelb.edu.au)

Received: 28 February 2017 - Discussion started: 17 March 2017

Revised: 10 August 2017 - Accepted: 1 September 2017 - Published: 26 October 2017

\begin{abstract}
Non-annually resolved palaeoclimate records in the Australasian region were compiled to facilitate investigations of decadal to centennial climate variability over the past 2000 years. A total of 675 lake and wetland, geomorphic, marine, and speleothem records were identified. The majority of records are located near population centres in southeast Australia, in New Zealand, and across the maritime continent, and there are few records from the arid regions of central and western Australia. Each record was assessed against a set of a priori criteria based on temporal resolution, record length, dating methods, and confidence in the proxy-climate relationship over the Common Era. A subset of 22 records met the criteria and were endorsed for subsequent analyses. Chronological uncertainty was the primary reason why records did not meet the selection criteria. New chronologies based on Bayesian techniques were constructed for the high-quality subset to ensure a consistent approach to age modelling and quantification of age uncertainties. The primary reasons for differences between published and reconstructed age-depth models were the consideration of the non-singular distribution of ages in calibrated ${ }^{14} \mathrm{C}$ dates and the use of estimated autocorrelation between sampled depths as a constraint for changes in accumulation rate. Existing proxies and reconstruction techniques that successfully capture climate variability in the region show potential to address spatial gaps and expand the range of climate variables covering the last 2000 years in the Australasian region. Fu-
\end{abstract}

ture palaeoclimate research and records in Australasia could be greatly improved through three main actions: (i) greater data availability through the public archiving of published records; (ii) thorough characterisation of proxy-climate relationships through site monitoring and climate sensitivity tests; and (iii) improvement of chronologies through coretop dating, inclusion of tephra layers where possible, and increased date density during the Common Era.

\section{Introduction}

\subsection{Background}

Elucidation of climate system variability and long-term change requires a spatially and temporally robust baseline of natural climate conditions. This is particularly relevant for Australasia, where climate variability has strong agricultural, socioeconomic, and environmental impacts (Head et al., 2014; Kiem et al., 2016; van Dijk et al., 2013). The Intergovernmental Panel on Climate Change (IPCC) previously supported a 2000-year baseline to establish climate variability for Earth (Masson-Delmotte et al., 2013). This time period is ideal for providing an effective context for three primary reasons: (i) shifts in global boundary conditions are believed to be minor and well constrained over this time frame; (ii) the last 2 millennia contain periods of relatively warm and cool climate anomalies, which offers the 
opportunity to study regional responses to global and/or regional climate fluctuations; and (iii) the majority of highresolution proxy climate records occur within this period, which provides reconstructions of climate at individual sites and across geographic regions with increased chronological certainty (PAGES2k Consortium, 2013; Neukom and Gergis, 2012).

The International Geosphere-Biosphere Programme-led Past Global Changes (PAGES) Regional 2k initiative was established in 2008 to coordinate and synthesise regionaland continental-scale reconstructions spanning the last 2000 years. This network also provides a way to exchange ideas and test hypotheses about recent palaeoclimates that can be queried using consistent quality-controlled data sets. The PAGES initiative encourages the use of rigorous, multimethod approaches to compare variability, patterns, and timing of changes across regions (Kaufman, 2014). The Aus2k working group investigates Australasian climate variability over the last 2000 years, hereafter referred to as the Common Era (CE).

Data derived from natural archives for the purpose of investigating climate variability fall into two categories: high resolution (monthly to annually resolved) and low resolution (non-annually resolved). High-resolution archives, such as tree rings, corals, varved sediments, and some ice cores, have been used to reconstruct regional and global temperature trends over the Common Era (PAGES2k Consortium, 2013; Gergis et al., 2016; Mann, 2007; Mann and Jones, 2003). In addition to several advantages of using annually resolved data, such as chronological precision and temporal resolution, annually resolved data possess some limitations when examining the past 2 millennia. These limitations can include the confined spatial coverage inherent to the high-resolution data network and difficulties in capturing low-frequency variability (Anchukaitis and Tierney, 2012). The limitations of interpreting low-frequency signals in highresolution archives are exemplified with tree rings, for which multiple short, individual series are used to compile longer composite chronologies. The applied standardisation techniques used to construct the composite chronologies can restrict meaningful long-term signal retention, referred to as the "segment length curse" (Cook et al., 1995).

Due to the limited potential of reconstructing multidecadal and longer-term variability from high-resolution archives, it is important to complement the resulting reconstructions with non-annually resolved, low-resolution records (Moberg et al., 2005). Previous studies have explored combining high- and low-resolution archives in the Australasian region to investigate a range of climate variables and atmospheric circulation patterns (Goodwin et al., 2013, 2014; Lorrey et al., 2007, 2008). Annually resolved records in the Southern Hemisphere (including Australasia) have been identified, reviewed, vetted, and augmented (Neukom and Gergis, 2012), but no equivalent synthesis of non-annually resolved records in the Australasian region currently exists.

Low-resolution sedimentary archives available within Australasia include lacustrine, fluvial and wetland sediments (including peat), marine sediments, speleothems, and geomorphic features (e.g. moraines, dunes) across diverse climate settings. These archives have multiple strengths for use in palaeoclimate reconstructions. First, the typical length of low-resolution records ( $>500$ years) is longer than many available annually resolved records. Data processing techniques for low-resolution sedimentary archives also tend to preserve low-frequency climate signals, i.e. those over multicentennial and longer time frames. Second, low-resolution archives have a greater potential to be more widely distributed in comparison to annually resolved archives for most regions (Anchukaitis and Tierney, 2012). This is especially true in the ocean-dominated Southern Hemisphere. For example, marine sediment cores can provide records of oceanic variability without the tight climatic and bathymetric constraints of coral records. Other low-resolution archives such as speleothems and lake sediments can provide continuous records from climate regions spanning arid regions (Gliganic et al., 2014; Quigley et al., 2010) to the tropics (Crausbay et al., 2006; Rodysill et al., 2013). Third, the climate signals preserved in low-resolution records can differ from those found in annually resolved records, meaning that a wider range of long-term climate changes, as well as differing types of climate variability, can be reconstructed through their inclusion in multi-proxy syntheses.

\subsection{Aims}

To date, Australasia has hundreds of published lowresolution palaeoclimate records. However, a comprehensive palaeoclimate record database has not been compiled and evaluated for suitability to contribute to the examination of climate variability during the Common Era. In this study, low-resolution palaeoclimate data sets for Australasia were compiled and assessed for their suitability for quantitative climate reconstruction efforts. Records were assessed against a set of predetermined quality metrics to develop a subset of suitable records that could then be presented in a flexible, consistent format to facilitate future palaeoclimate investigations in the region. The four objectives of this study are to (i) identify Australasian palaeoclimate records spanning the last 2000 years, (ii) evaluate each record against the criteria set out by the global PAGES2k network, (iii) recalibrate age-depth models of the resulting subset of records using Bayesian techniques, and (iv) discuss merits and shortcomings of existing palaeoclimate reconstructions while providing recommendations for future palaeoclimate record collection and development for the Australasian scientific community.

The work compliments a recent review of all annually resolved records in the Southern Hemisphere cover- 
ing the Common Era (Neukom and Gergis, 2012), as well as other subregion synthesis efforts in Australasia (Freeman et al., 2011; Gouramanis et al., 2013; Lorrey et al., 2007, 2008, 2010). The outcomes of this study will be helpful to researchers by identifying the most reliable lowresolution records in the Australasian region for climate model-palaeoclimate data intercomparisons in the Southern Hemisphere (Phipps et al., 2013).

\section{Data and methods}

Records published before 2017 were identified through inspection of citation databases, reference lists of past review papers, online public data repositories, personal communication with authors, and a general inquiry to all Australasian Quaternary Association members. Data were retrieved from the NOAA palaeoclimate database (https://www.ncdc. noaa.gov/data-access/paleoclimatology-data), the Neotoma database (https://www.neotomadb.org), the PANGAEA data publisher (https://www.pangaea.de/), and directly from record creators.

\subsection{Defining Aus2k low-resolution palaeoclimate data criteria}

For this study, all assembled records were screened against a set of selection criteria for the purpose of identifying a high-quality subset for the use of the PAGES Aus2k working group. The selection criteria, outlined below, follow those designated by the international PAGES Regional 2k initiative (http://pastglobalchanges.org/ini/wg/ $2 \mathrm{k}$-network/data). For inclusion, a record was required to meet the following five criteria:

i. The proxy must be related to one or more climate variables, as stated in a peer-reviewed publication.

ii. The record must extend continuously for at least 500 years out of the last 2000 years.

iii. The record must have an age model based on at least two to three chronological anchors.

iv. The record must have an average sample resolution between 2 and 50 years per sample or analysis.

v. The collection location must fall within the region that has been identified by PAGES Aus2k to influence Australasian climate $\left(90^{\circ} \mathrm{E}-140^{\circ} \mathrm{W}, 10^{\circ} \mathrm{N}-80^{\circ} \mathrm{S}\right)($ Gergis et al., 2016). The Australasian region includes tropical Southeast Asia because of the dynamical influences of the Indo-Pacific region on the Australasian monsoon (Meehl and Arblaster, 2002), as well as the AustralianNew Zealand sector of the Southern Ocean and Antarctica because of oceanographic and atmospheric teleconnections (Hall and Visbeck, 2002; van Ommen and Morgan, 2010).
The application of each criterion was justified on several grounds. First, records must have a published, peerreviewed interpretation of the relationship between the measured proxy and climate variable(s). This provides quality control through the traditional peer review process by palaeoclimate specialists. Second, the overall length and average sample resolution have been selected for the purpose of reconstructing climate variability at a range of timescales over the Common Era. It is important that the data have sufficient resolution to capture fluctuations at multi-decadal scales and that they are long enough to capture an appropriate number of cycles in the study period (Chen and Grasby, 2009). Third, the low-resolution records must have reasonable chronological constraints. Reasonable was defined by PAGES2k as containing at least one chronological control point near the youngest part of the record, another near $1 \mathrm{CE}$ or the end of the record (whichever is younger), and, for records greater than 1000 years in length, an additional date near the middle of the record. Many records, primarily in the marine realm, extend beyond the Common Era. Dates outside this period were retained to constrain interpolation uncertainties at age model extremes. The final requirement is that records must be publicly available, which contributes towards the transparency and reproducibility of results. All of the records identified within the Aus $2 \mathrm{k}$ region have been previously published, but very few were publicly available. One of the tasks undertaken by the Aus $2 \mathrm{k}$ working group was to ensure that all records were stored in public archives. All Aus2k data sets are available through the NOAA palaeoclimate archive or PANGAEA data publisher (https://www.pangaea.de) (Table 1).

Preservation of metadata relating to the Aus $2 \mathrm{k}$ data sets will assist future computer-driven, multi-record comparisons and reconstructions. One recent initiative of the palaeoclimate community is the development of a "common language" of palaeoclimatology, in which data and metadata are stored in a consistent, machine-readable format (Emile-Geay and Eshleman, 2013; McKay and Emile-Geay, 2015). The Linked Paleo Data (LiPD) framework has been developed with input from the wider scientific community (McKay and Emile-Geay, 2015). The metadata retained for the Aus2k data sets are based on the fields in the LiPD framework. As a part of the metadata, raw age determinations are recorded. Although one approach for the creation of age models is presented in this study, the raw data are available for individuals who wish to apply alternative methods.

\subsection{Past palaeoclimate data syntheses in Australasia}

Previous palaeoclimate and palaeoenvironmental reviews have compiled lists of studies and obtained proxy data to address a range of research questions from the Australian and New Zealand sectors. Australian palaeoclimate records containing at least one date in the Holocene were compiled through a partnership between Macquarie University 

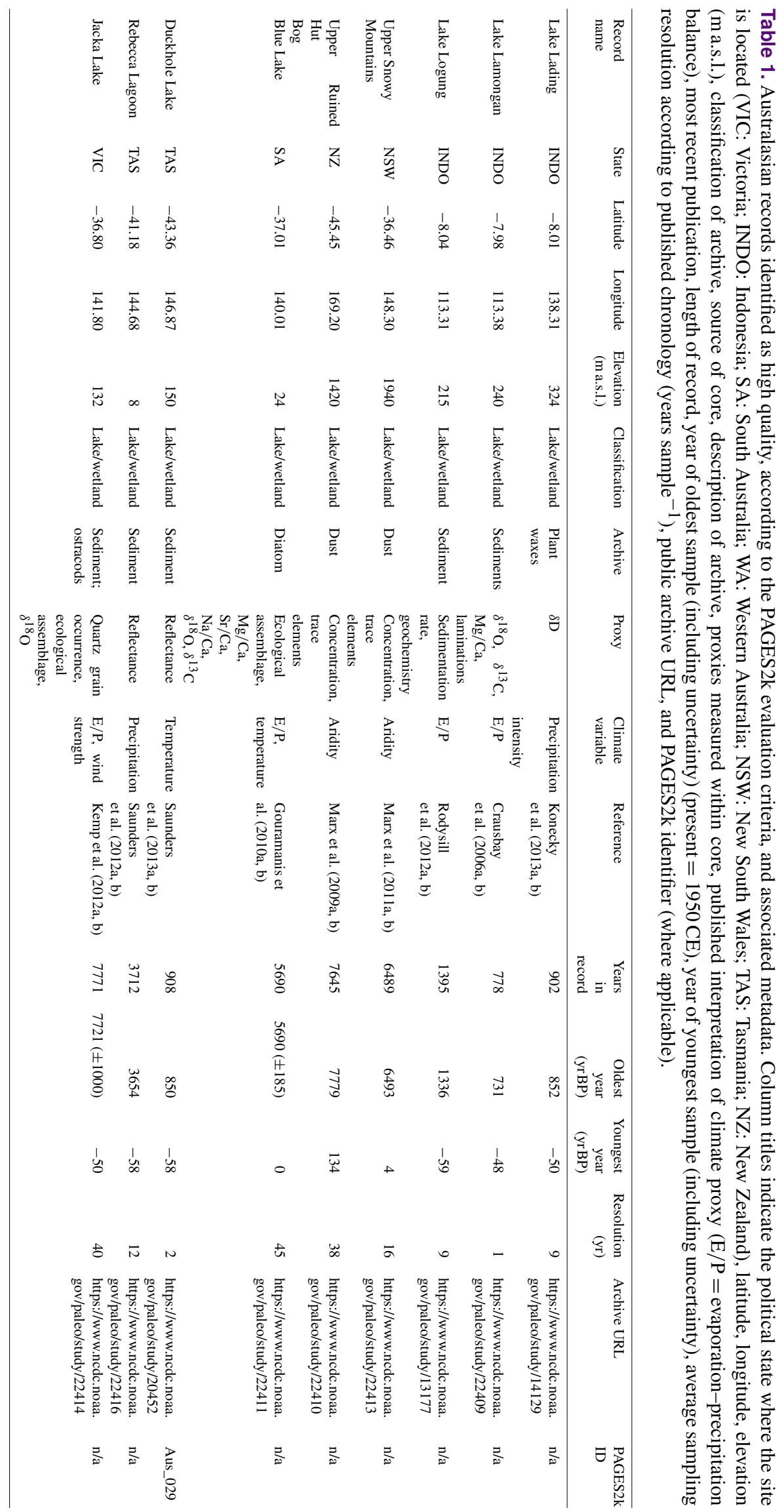


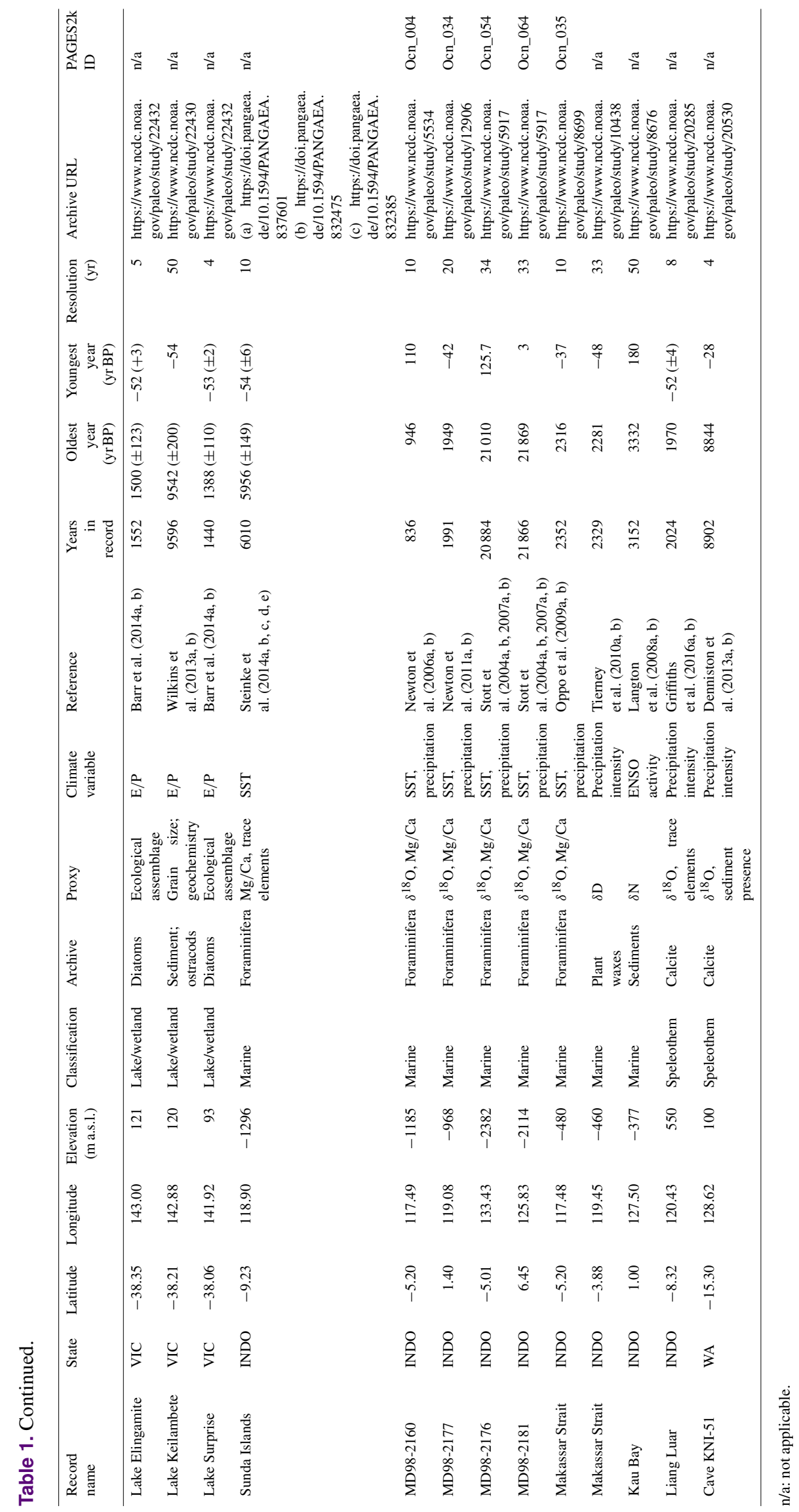


and the New South Wales Department of Environment, Climate Change, and Water (Freeman et al., 2011). The review identified 190 low-resolution records and 51 high-resolution records. Of these 241 records, 141 were classified as "moderate to high confidence" based on climatic sensitivity, possible non-climatic influences, local forcing, and chronological confidence. Gouramanis et al. (2013) compiled a set of records for a latitudinal transect across the Australian continent that is used to compare consistency in climate histories between eastern and western Australia over the past $\sim 8000$ years. The data sets were chosen by the reputation of the published records, based on the regularity of citation.

Other groups within Australasia have previously conducted multi-proxy palaeoclimate syntheses under the banner of AUS-INTIMATE (Australasian INTegration of Ice, MArine, and TErrestrial records). Records identified through this initiative have benefitted the most recent PAGES2k effort to evaluate and update the last 2000 years. AUS-INTIMATE was organised within the International Union for Quaternary Research (INQUA), with two distinct research phases from 2004 to 2007 and from 2008 to 2011. Both NZ- (New Zealand) and OZ- (Australia) INTIMATE projects focused on the interval $30000-8000$ years ago (Alloway et al., 2007; Barrell et al., 2013; Bostock et al., 2013; Reeves et al., 2013b); however, many of the compiled records extend to the present. The purpose of AUS-INTIMATE was to integrate available proxy data into climate event stratigraphies. AUSINTIMATE coverage has been extended from 8000 years ago to present via the Southern Hemisphere Assessment of PalaeoEnvironments (SHAPE) project supported by INQUA since 2013.

New Zealand palaeoclimate proxies covering several late Quaternary intervals, including the last 2000 years, were compiled prior to and during Phase I of Aus2k (Lorrey et al., 2008, 2010) to address how regional atmospheric circulation has changed during the late Holocene. The New Zealand data assemblage for the last 2000 years included 35 low-resolution (multi-decadal to centennial) hydroclimatically sensitive records. These data were compiled from the site level up to a homogeneous regional climate district level (Kidson, 2000; Lorrey et al., 2007) from a range of environments that range from temperate subtropical in the far north of New Zealand to glacial in the south. From studies that had undertaken multi-decadal binning of annually resolved temperature reconstructions 13 temperature-sensitive records were obtained. There are also several speleothem stable isotope series for New Zealand that cover the Holocene, including the last 2000 years (Lorrey et al., 2008, 2010; Lorrey and Bostock, 2017). In addition, two compilations of past Southern Alps glacier activity (summarised from Lorrey et al., 2008, and Schaefer et al., 2009) and a summer mean surface pressure anomaly reconstruction (after Villalba et al., 1997) completed the New Zealand low-resolution data set that is relevant for Aus $2 \mathrm{k}$. In the interest of not duplicating data pre- viously included in the Aus2k high-resolution compilation, the New Zealand tree ring data are excluded here.

Additional global syntheses are also drawn upon in this study. The charcoal database presented by Mooney et al. (2011) is the Australasian subset of a global charcoal database (Power et al., 2010) and contains all data sets (published and unpublished) up until 2011 that include charcoal analyses. The OZPACS working group under the Australasian Quaternary Association (AQUA) was created to investigate ecosystem changes and human impact on the landscapes over the last 500 years. One outcome of the initiative was a list of records until 2007 that covered the target period (Fitzsimmons et al., 2007).

\subsection{Caveats on resolving changes from low-resolution sedimentary records}

Despite the benefits of low-resolution archives, these records often contain relatively large errors associated with radiometric dating techniques (Anchukaitis and Tierney, 2012; Moberg et al., 2005) and uncertainty associated with using age-depth models to predict ages of undated layers (Trachsel and Telford, 2017; Telford et al., 2004). Age ambiguity leads to difficulty in cross-correlating records. These errors can result from three primary complications in radiocarbon dating techniques: dead carbon contamination, multiple possible calibrated ages associated with measured ${ }^{14} \mathrm{C}$ values, and inbuilt ages (McFadgen, 2007).

Radiometrically "old" or "dead" carbon derived from groundwater and/or carbonate rocks can drastically alter the apparent ${ }^{14} \mathrm{C}$ age of freshwater bodies (Geyh, 2000) and the organisms that live within or near the water (Beavan-Athfield and Sparks, 2001). The possibility of contamination by old carbon can be minimised through the use of short-lived plant macrofossils (Blois et al., 2011), when present, as well as dating of modern water samples to identify the presence of an old carbon reservoir (e.g. Gouramanis et al., 2010). Fluctuations in atmospheric ${ }^{14} \mathrm{C}$ through time may result from aperiodic changes in ocean-atmosphere-terrestrial radiocarbon partitioning, upper-atmosphere radiocarbon production, and oceanic upwelling dynamics (Rodgers et al., 2011) that lead to "wiggles" in the radiocarbon calibration curve. When this is pared with the measurement uncertainty of radiocarbon samples, it leads to a range of possible calendar dates (Blaauw, 2010). The inbuilt age of samples may have multiple components that influence dating uncertainties. These include incorporated age (i.e. chronologically old material contained in an organism that pre-dates its death, as with longlived trees) and environmental residence time (also termed "storage age"), which is the elapsed time between the death of the dated organism and deposition of its remains in a dated horizon (McFadgen, 1982). The most common example of this phenomenon is the preservation of long-lived trees in the landscape before deposition in sediment (see Grant, 1985, for an example related to alluvial sedimentation). 
It is not always possible to identify environmental residence time within a radiocarbon sample, and the uncertainty may not be acknowledged within the resulting chronology (McFadgen, 2007). In some cases, anatomical studies may reveal whether incorporated age is large or minimal (e.g. identifying heart wood vs. sapwood in tree samples). Methods exist to attempt to classify the relationship of a radiometric age to a horizon of interest; for example (i) a close age is a radiocarbon date from within or directly adjacent to the horizon of interest, which is assumed to have a minimal inbuilt age, due to the type of material; (ii) a minimum age is derived from a sample with a minimal inbuilt age, which has been collected stratigraphically above the horizon or event of interest; and (iii) a maximum age is derived from a sample with minimal inbuilt age, which has been collected from a horizon below the horizon or event of interest (McFadgen, 2007). Overall, the use of close ages within a horizon of interest, in conjunction with bracketing by minimum and maximum ages, assists in decreasing uncertainty in dating individual events. Estimated inbuilt ages for some common New Zealand plant species have been published (McFadgen, 2007), but less emphasis has been placed on this subject in Australian studies.

Identifying a high-quality subset of records allows both an inter-comparison of records and helps to answer questions of climatic consistency between or within regions (Tyler et al., 2015). Two factors that complicate comparison of published studies are the reliance on calibrated conventional radiocarbon ages (CRAs) and the wide range of methods that are currently used in age-depth modelling. The conversion of CRAs to calendar timescales can have variable results because of updates to the atmospheric radiocarbon calibration curve (Reimer et al., 2013). Furthermore, the calibration curves that are used to convert conventional CRAs to calendarequivalent timescales have variable precision through time (Reimer et al., 2013). Both factors result in changes to the slope of and variability in the calibration curve; thus, multiple statistically significant calendar age possibilities exist for CRAs on organic material. As such, the probability distribution ranges for calibrated CRAs (and therefore their temporal uncertainty) can be large ( $>100$ calendar years) for some time periods in the last 2000 years (Anchukaitis and Tierney, 2012).

The recalibration of CRAs with the most up-to-date calibration curve can assist in improving the representation of the uncertainty for radiocarbon dates (Blaauw, 2010). A further source of age model uncertainty comes from the interpolation or modelling of ages between dated layers, an uncertainty that decreases proportionally to the number of age constraints. Traditional age modelling approaches, including linear regression and polynomial equations, treat age uncertainty within dated horizons and interpolated ages between chronological anchors differently. Age model uncertainty can be minimised by overlapping age probability distribution functions through a sedimentary sequence, but this is not always possible due to the cost of radiocarbon dating and availability of suitable material. Current age modelling techniques are capable of quantifying interpolation uncertainty when deriving age-depth relationships (Goring et al., 2012; Blaauw and Christen, 2011; Bronk Ramsey, 2009; Hua et al., 2012). Probability functions at each dated horizon are calculated, and then accumulation behaviour between these horizons is iteratively resampled to create thousands of possible time series. The probability distributions allow for the consideration of the non-singular nature of age calibrations for individual radiocarbon dates that form the anchors of a chronology (Hogg et al., 2013; Reimer et al., 2013).

\subsection{Age model recalibration}

One of the most commonly used software packages for constructing age models is "bacon" (Bayesian accumulation histories) (Blaauw and Christen, 2011), which is run through the R statistical package (R Core Team, 2015). Within the software, a priori information ("priors") informs the outcome of the statistical tests - namely the sampling interval, memory strength, and accumulation rate. Prior values can be set, based on existing knowledge of particular archives and/or study sites (e.g. Hua et al., 2012; Goring et al., 2012), and varied by the program to determine the best fit (Blaauw and Christen, 2011). The sampling interval prior is an estimate of the realistic physical distance over which the accumulation rate can change. It is not possible to know for certain if there are shifts in accumulation rate within one physical sample; thus, changes are restricted to sampling intervals.

Memory strength refers to the extent to which the accumulation rate of one section relies on that of the previous section (i.e. the degree of autocorrelation), or the likelihood of a rapid shift in the accumulation rate. For example, speleothems are observed to have minimal memory effect (Scholz et al., 2012); therefore, the memory prior should be lowered from the default (Hua et al., 2012). For the Aus2k data sets, accumulation rate has been estimated from the published age-depth model. Even if the published accumulation rate was inaccurate, the program considers how well the priors agree with the accumulation rate suggested by the data. This also allows for non-linear accumulation rates (Goring et al., 2012), which is an important consideration in the Australasian context. For example, a rapid increase in sedimentation rate is known to correspond to European settlement in Australia (Gell et al., 2009) and changes in land cultivation practices in the Malay Archipelago (Gharibreza et al., 2013; Rodysill et al., 2012).

Bacon uses Student's $t$ distributions for radiocarbon dates, which have wider tales than normal distributions (Blaauw and Christen, 2011). This distribution is chosen with the intention of including the maximum number of dates in an age-depth model and decreasing the need to remove outliers. In this study, decisions of the original authors were upheld in the recalibration of age models, including the exclusion 
of radiocarbon dates due to inversion or contamination. Radiocarbon dates at terrestrial sites were recalibrated with the SHCal13 calibration curve (Hogg et al., 2013), while marine radiocarbon dates were recalibrated with the Marine13 curve (Reimer et al., 2013). Any radiocarbon reservoir effects identified by the original authors were applied during age-depth model construction. Overall, the approach used in this study maintains the specialist knowledge of the original authors, while updating records using a common statistical method for the development of age models and the calculation of uncertainty estimates.

\section{Results}

\subsection{General attributes of Australasian palaeoclimate data}

The complete compilation of Australasian records contains 675 records (Table S1 in the Supplement), shown in Fig. 1. The areas of high data availability occur around the coastal population centres of Australia, with density decreasing with increasing distance from cities. The Malay Archipelago has a moderate, yet spatially even coverage. New Zealand has data available across the country, with the majority of records located within the northern and eastern North Island and the western South Island districts (Lorrey et al., 2008, 2010). Karst terrain extends in small patches along the length of both main islands in New Zealand. This has resulted in individual and composite speleothem records that have been used to infer past regional climate conditions (Lorrey et al., 2007). The most common source of terrestrial palaeoclimate information for both New Zealand and Australia is pollen, followed by biotic microfossils. Geochemical analysis of foraminifera is the most common proxy in marine cores (Table S1). There are a number of study sites at which multiple proxies have been analysed, particularly pollen and charcoal in terrestrial cores, and $\delta^{18} \mathrm{O}$ and $\mathrm{Mg} / \mathrm{Ca}$ of foraminifera in marine cores (Table S1).

As seen in Fig. 2, the length of records varies dramatically. Some lake sediment records focus on environmental change over decades (e.g. Tibby et al., 2010), while some marine cores extend into the Pleistocene (e.g. Van der Kaars and De Deckker, 2002). For many records, the youngest age is not precisely known, but the original authors assume the core top reflects the collection year or "present" (1950 CE). Some records are presented as having annual or sub-annual resolution (e.g. Martin et al., 2014); however, many of these records are not constrained by annually resolved markers. These types of records are regarded as non-annually resolved records in this study.

\subsection{Results of PAGES Aus2k screening}

When the PAGES selection criteria outlined in Sect. 2.1 were applied to all Australasian records, a subset of 22 records

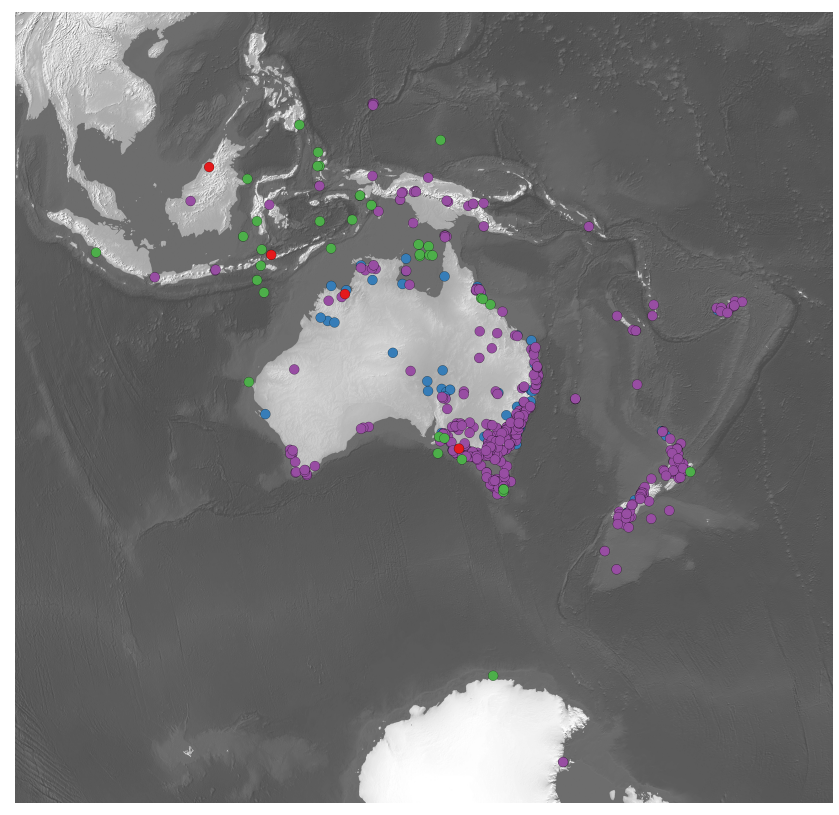

Figure 1. Map of all Australasian records identified. Each marker represents one record location. Archive types are represented by colour for lake/wetland/peat (purple), marine (green), speleothem (red), and geomorphic (blue) archive types.

met the stringent quality requirements (Table 1). Within this screened Aus $2 \mathrm{k}$ subset, the two areas with greatest geographical coverage were southeast Australia and the Indonesian Malay Archipelago (Fig. 3). This follows the pattern seen in the complete data set (Fig. 1). Records from Indonesia are predominantly marine $(n=8)$, but also include four terrestrial records. Eight lake and wetland records are located within southeast Australia, and one speleothem record is located within western Australia. One record is physically located in New Zealand, but as a record of dust accumulation, it is interpreted to be a proxy for Australian climate (Marx et al., 2009). Lacustrine microfossils are the most common terrestrial proxy in the Aus $2 \mathrm{k}$ records, while foraminifera geochemistry is the predominant marine proxy. Average sample resolution varies; eight records have a resolution of less than 10 years sample ${ }^{-1}$, including six lake cores and two speleothems. Other records resolve decadal to multi-decadal timescales.

\subsection{Age model updates}

The age models for all Aus2k records in Table 1 were recalibrated using the techniques outlined in Sect. 2.4. The extent of change in the minimum and maximum ages, as well as timing of anomalous events, varies within the Aus $2 \mathrm{k}$ data sets (Figs. 4 and S2). Examples of recalibrated chronologies are shown in Fig. 4. 

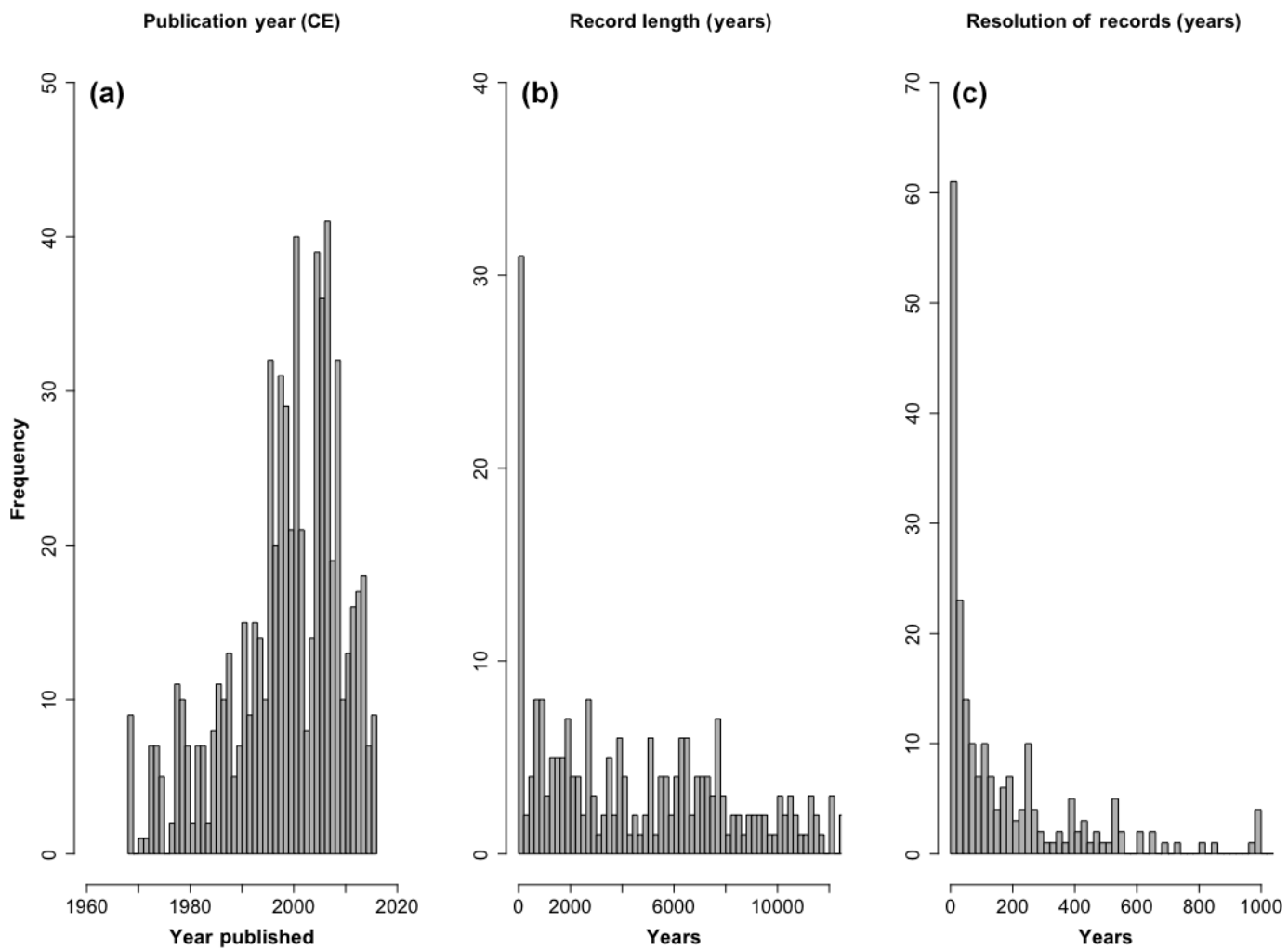

Figure 2. Metadata for all Australasian records. Data are presented for (a) publication year for most recent presentation of each record, (b) length of time between the oldest and youngest samples (where possible to calculate), and (c) sampling resolution (years sample ${ }^{-1}$ ) of the record (where possible to calculate for lake/wetland, speleothem, and marine records).

\section{Discussion}

The results presented here are the first comprehensive collection of Australasian sedimentary records that cover the last 2000 years. Few records are currently publicly available through the data archives outlined in Sect. 2. There is moderate spatial and temporal coverage of existing records across the geographic network (Figs. 1 and 2), with the exception of poor coverage for arid central and western Australia. Although there are proxies from the arid region that cover longer time frames over the Quaternary (Fitzsimmons et al., 2013), most available records do not have the continuity and resolution to investigate climate variability during the Common Era. The resolution of most Australasian records falls between 2 and 300 years (Fig. 2), which is suitable for examining variability on multi-decadal to centennial timescales. A low number of radiocarbon dates and/or low confidence in the chronologies are the most common reasons for record exclusion from the Aus $2 \mathrm{k}$ data set. Therefore, even if record length and resolution are ideal for examining climate variability over the last 2000 years, age model uncertainties mean that it would be difficult to draw conclusions on the timing of events.

\subsection{Composition of the low-resolution Aus2k data set}

The 22 records that meet the PAGES2k selection criteria provide a subset of records with robust chronologies, an identified proxy-climate relationship, and sufficient record length and resolution to investigate decadal to centennial variability during the last 2000 years. The number of high-quality records is very low in comparison to the total number of palaeoclimate records identified and assessed. The low acceptance rate of records into the Aus $2 \mathrm{k}$ database (3\%) may reflect regionally specific problems of sparse and discontinuous sediment records and poor preservation of macrofossils for radiocarbon dating due to sparse vegetation, in addition to a historical focus on other aspects of Quaternary research in the Australasian region.

The geographic distribution of Aus2k records displays stronger spatial biases than the complete regional database (Fig. 3). Southeast Australia has seven records, likely due to the ease of access to locations proximal to major cities with research institutions, and a relative abundance of lakes and wetlands. In contrast, the availability of high-quality records in Indonesia relates to global interest in the region as a dynamical "centre of action" for numerous climate drivers including the El Niño-Southern Oscillation (ENSO), the Indian Ocean Dipole (IOD), and the Australian-Indonesian 


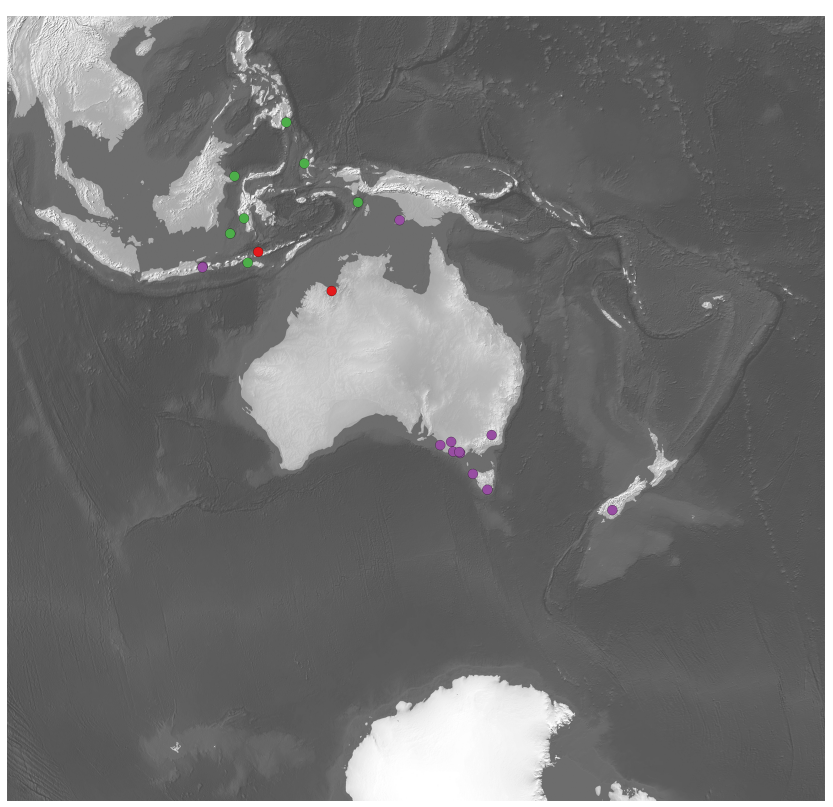

Figure 3. Locations of high-quality Aus2k records. Each marker represents one record location. Archive types are represented by colour for lake/wetland (purple), marine (green), speleothem (red), and geomorphic (blue) archive types.

summer monsoon (AISM), resulting in high levels of international funding for research in this area.

While New Zealand has a high number of sites that could potentially contribute more to understanding palaeoclimate of the last 2000 years, many records fail to pass the Aus $2 \mathrm{k}$ criteria. The main reasons for New Zealand records not meeting the selection criteria are lack of an established proxyclimate variable relationship, insufficient sampling resolution, or the use of composite chronologies that require care in interpretation. Nonetheless, it is clear from the New Zealand proxy assemblages that the presence of tephras and pollen markers can improve the chronostratigraphic constraints associated with ${ }^{14} \mathrm{C}$ dates as applied in many cores. Some sites also show potential to be revisited to improve age controls, sample at higher resolution, and calibrate proxy data against instrumental records to develop a reliable climate reconstruction (Roop et al., 2015).

The subset of 22 high-quality records that meet the Aus $2 \mathrm{k}$ criteria includes a range of lacustrine sediment cores, marine cores, speleothems, and two peat cores. These archives are best suited for examining decadal to multi-decadal variability due to their accumulation rate, continuity, preservation, and dating potential. A brief description of archives and their applicability to studying climate variability during the Common Era is provided below.

\subsubsection{Lakes, wetlands, and peatlands}

The majority of palaeoclimate records in Australasia are sediment cores from lake and wetland environments (Figs. 1 and 3). The length of lake and wetland records can vary greatly, including short, high-resolution records that focus on inter-annual changes and long, low-resolution records that cover hundreds of thousands of years (Fig. 2). Cores are analysed for both biogenic and inorganic proxies. Peat bogs can be ideal sources of sediment cores because of high accumulation rates and the capture of a variety of organic and non-organic components (Barber et al., 1994; Booth et al., 2010). Peat is a promising archive within Australasia due to the large longitudinal coverage; mires are found from tropical locations in Papua New Guinea to the subantarctic islands (McGlone, 2002b; McGlone et al., 2010; Whinam and Hope, 2005). Most peat-based records in Australasia contain pollen and charcoal that may be used for palaeoclimate, palaeoecology, and palaeo-fire reconstructions (Whinam and Hope, 2005; Mooney et al., 2011). Degree of humification has also been applied as a hydroclimate indicator in the late Holocene (Burrows et al., 2014; Wilmshurst et al., 2002) in cores for which dating density is sufficient.

A possible limitation in the Australasian context is the assumption of a stable relationship between sediment properties and climate variables over long periods of time. Humans have likely impacted Australian wetland ecosystems for the entire duration of the Holocene (Fletcher and Thomas, 2010b; Black et al., 2007), and an impact has been recognised in New Zealand during the last millennium (Horrocks et al., 2007; McGlone and Wilmshurst, 1999b). This anthropogenic influence has intensified across Australasia since the arrival of European settlers (Gell et al., 2007; Bickford and Gell, 2005; McGlone and Wilmshurst, 1999a), which may lead to palaeolimnological signals unrelated to climate. The primary consideration in lake-, wetland-, or peat-derived climate archives is a clear understanding of the modern proxyclimate relationship, including the geomorphic, hydrological, geochemical, and biological responses, most of which are complex and non-linear (Adrian et al., 2009; Winder and Schindler, 2004). Site-specific factors such as sediment accumulation rate, basin morphology, and hydrological balance may potentially have a strong impact on the preservation of climate signals (Wigdahl et al., 2014). Detailed understanding of these relationships relies on local monitoring programs or comparisons between observed proxy behaviour and instrumental records over a sufficient length of time. Development of mechanistic response models is also a priority in order to quantify the sensitivity of certain proxies to hypothetical changes, as well as to integrate the multiple climate effects upon a particular palaeoclimate record.

The most common approach for characterising modern proxy-limnology-climate relationships in Australia is the "calibration in space" of lake- and wetland-derived proxies, for which lakes across an environmental gradient are sam- 

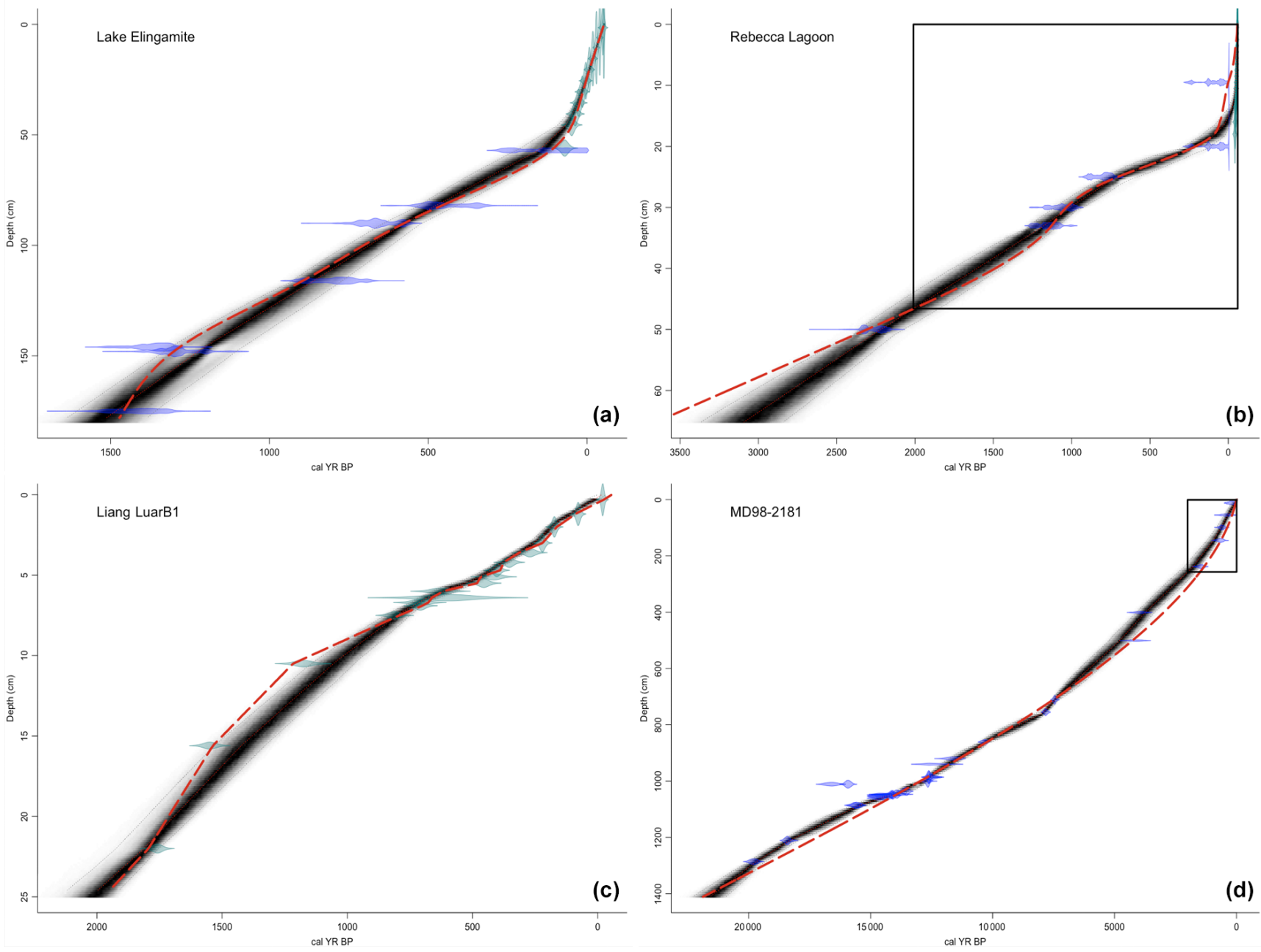

Figure 4. Examples of bacon outputs for recalibrated age-depth models for (a) Lake Elingamite; (b) Rebecca Lagoon; (c) Liang Luar Cave; (d) marine core MD98-2181. Originally published age-depth relationships were retrieved from public archives (Table 1) and are displayed by a dashed red line. The Common Era is highlighted by a black rectangle in records that extend beyond the last 2000 years.

pled for the purpose of identifying these relationships (Gell, 1997; Saunders, 2011). In addition, "calibration in time" has been performed, whereby a proxy time series is calibrated with instrumental meteorological time series data to produce a predictive transfer function for quantitative reconstruction beyond the calibration period (Larocque-Tobler et al., 2011; von Gunten et al., 2012; Cook et al., 1994). Two studies within the Aus2k data set have used 20th century instrumental precipitation and temperature data for calibration of longer records of sediment reflection data (Saunders et al., 2013, 2012).

\section{Ostracods}

Ostracods, small carbonate bivalve crustaceans, have been used as palaeosalinity and lake level indicators in southern Australia for over 3 decades (De Deckker, 1982; Gouramanis, 2009). The regular moulting of valves throughout the organisms' lifetime means that there is a rapid response time of calcite accretion to changes in the lake environment. Originally, observed salinity tolerances of modern species were used to infer palaeosalinity (De Deckker, 1982). More recently, transfer functions have been developed to translate fossil assemblages into quantitative salinity estimates through the use of spatial training sets for sites across southern Australia (De Deckker et al., 2011; Gouramanis et al., 2012; Gouramanis, 2009; Kemp et al., 2012). Reconstructed lake water salinity fluctuations are interpreted to reflect precipitation-evaporation $(\mathrm{P} / \mathrm{E})$ balance, assuming minimal groundwater flow into and out of the lake basin.

Geochemical analysis of ostracod valves is another proxy used to reconstruct lake chemistry and water temperature. Monitoring of modern lacustrine systems has led to detailed understanding of controls on ostracod valve chemistry in Australian lakes. Valve $\mathrm{Mg} / \mathrm{Ca}$ records are affected by both lake water $\mathrm{Mg} / \mathrm{Ca}$ values and temperature (Chivas 
et al., 1986). For much of the ostracod research in Australia, valve $\mathrm{Sr} / \mathrm{Ca}$ has been interpreted as a proxy for water Sr/Ca (Chivas et al., 1985, 1986) with a possible temperature influence (De Deckker et al., 1999). Recent studies argue that alkalinity is also an important influence on valve $\mathrm{Sr} / \mathrm{Ca}$ (Gouramanis and De Deckker, 2010). Stable isotope analyses are also undertaken on the carbonate valves. Oxygen isotope values reflect the combined influence of the oxygen isotopic composition and temperature of the lake water, while carbon isotopes reflect the isotopic composition of the dissolved inorganic carbon present in the lake system (see Gouramanis et al., 2010, and references therein).

Detailed ostracod-based investigations of climatic and environmental change, as well as salinity reconstructions indicative of $\mathrm{E} / \mathrm{P}$ balance, are available for Blue Lake in South Australia (Gouramanis et al., 2010), Barker Swamp in Western Australia (Gouramanis et al., 2012), Lake Keilambete and Lake Gnotuk in southern Victoria (Wilkins et al., 2013), and lakes in the northern region of Victoria (Kemp et al., 2012). Although the sample resolution at Barker Swamp and Lake Gnotuk precludes the inclusion of the sites in the Aus2k data set, all of these sites possess a salinity reconstruction. This diversity of proxies, as well as the high-resolution sampling of the sediment cores, has allowed for high-quality climate and environmental reconstructions based on Australian ostracod records.

\section{Diatoms}

Ecological assemblages of diatoms, siliceous unicellular algae, are used to create quantitative and qualitative climatic and environmental reconstructions for lake and river systems across Australasia. Diatom fossils are well suited to decadal to multi-decadal climate reconstruction because of their short lifespan and sensitivity to subtle changes in their environment. These characteristics facilitate rapid responses to shifts in environmental change and high-resolution sampling in sediment cores. Transfer functions, developed from modern calibration data sets, have been established for numerous aquatic variables in both estuarine (Logan and Taffs, 2013; Tibby and Taffs, 2011) and lacustrine (Gell et al., 2005) settings. Variables include conductivity and salinity (Barr, 2010; Barr et al., 2014; Gell, 1997; Saunders et al., 2007, 2008; Saunders, 2011), pH (Tibby et al., 2003), and nutrients (Logan and Taffs, 2013; Tibby, 2004). Detailed studies on short timescales have examined pre-European baselines and anthropogenic impact since European settlement in the 19th century through $\mathrm{pH}$ (Taffs et al., 2008), salinity, and nutrient (Saunders et al., 2008) reconstructions.

Two diatom-derived conductivity reconstructions for Lake Elingamite and Lake Surprise in western Victoria are included in the Aus2k data set (Table 1). Transfer functions for the lakes are based on 47 sites across southeast Australia, and reconstructions have been subject to multiple forms of quality control before being interpreted in a climatic framework
(Barr et al., 2014). In addition, both sites have chronologies based upon radiocarbon and ${ }^{210} \mathrm{~Pb}$ dates that constrain the timing of inferred climatic shifts. Date density along the core, in addition to dates near the bottom of the core, leads to reduced uncertainty for age estimates for each sample (Barr et al., 2014).

\section{Palaeo-water isotopes}

Plant wax deuterium $(\delta \mathrm{D})$, controlled by source water deuterium values, can be preserved in lake and marine sediment cores. Analysis of leaf $n$-alkanes can assist in the reconstruction of local precipitation $\delta \mathrm{D}$ values if the degree of fractionation between the leaf and water is known (Sachse et al., 2006). Two Indonesian sedimentary records within the Aus2k data set use $\delta \mathrm{D}$ measurements as a climate proxy: one terrestrial and one marine. Konecky et al. (2013) used terrestrial plant wax compounds in lake sediments to reconstruct rainfall amount, associated with AISM intensity. Tierney et al. (2010) analysed leaf waxes in material that had been transported offshore. The same controls on $\delta \mathrm{D}$ were assumed in both settings, with no impact by sediment transport in the marine core.

\section{Lithics}

The lithic fraction of sediment cores can provide information about climate-driven depositional environmental changes through time. In Australia, grain-size analyses have been used as lake level indicators in locations where the relationship between sediment size fraction and lake levels is well understood. The most heavily studied example is Lake Keilambete in Victoria (Bowler, 1981; Bowler and Hamada, 1971; Mooney, 1997; Mooney and Dodson, 2001; Wilkins et al., 2013). The Lake Keilambete lake level reconstruction is very commonly used for validation of other palaeoclimate records in the region. Recent high-resolution sampling of new cores, and the examination of new proxies within these cores, reinforces the interpretation of the grain size analysis (Wilkins et al., 2013). The dating density is also the highest of any of the Aus $2 \mathrm{k}$ records, with four new accelerator mass spectrometry radiocarbon dates and four optically stimulated luminescence dates within the last 2000 years in the most recent chronology (Wilkins et al., 2012).

Changes in transport into a lake, reflected by accumulation rate, can be driven by climatic changes such as surface run-off or wind strength, or changed catchment conditions due to human impact (Sloss et al., 2011; Zhang et al., 2011). A rapid increase in sedimentation rates associated with European settlement is seen across Australia. Studies of wetlands and lakes across southern Australia have revealed increases from 2- to 80-fold between pre-settlement and modern day (Gell et al., 2009; Hollins et al., 2011; Sloss et al., 2011). This phenomenon is important for separating human and climatic influences on sediment cores. The lacustrine records that are 
available across New Zealand contain evidence for discrete sedimentation events or sedimentation variability. Signatures of acute sedimentation are interpreted as rapid in-washing of coarse loads Lake Rotonuiaha: Wilmshurst et al., 1997; Lake Tutira: Eden and Page, 1998; Gomez et al., 2012; Round Lake: Chester and Prior, 2004) that could be influenced by climate and/or seismic variability. Some of the lithological changes observed in lake cores are suggested as a response to climatically driven increases and decreases in lake level (Lake Maratoto: Green and Lowe, 1985; Lake Poukawa: McGlone, 2002a). Other triggering factors for lake sedimentation that have been hypothesised and/or demonstrated include fluvial undercutting, anthropogenic impacts, weathering, and tectonically induced base level changes (Eden and Page, 1998).

Non-destructive analytical techniques for sediment cores are becoming more widespread in Australasian studies. These techniques, including reflectance spectroscopy (Saunders et al., 2012, 2013) and X-ray fluorescence (Fletcher et al., 2014), can be conducted at very high ( $<1 \mathrm{~mm}$ ) resolution, and are easily combined with other analyses for multiproxy studies.

Another important component of sediment deposits in Australia is the aeolian dust fraction. Dust deposition rates are a proxy for continental aridity and wind intensity, while spatial differences in deposition rates can suggest shifts in dust transportation pathways (Bowler, 1976; Hesse, 1994; Hesse and McTainsh, 2003). The method for classifying dust varies by site and depends on the sedimentary environment. For coastal study sites, the local quartz input from sand dunes is ignored, while remaining material is assumed to have been transported to the site via aeolian means (McGowan et al., 2008). For peat bogs, the mineral content is determined as the non-combustible fraction of dry peat mass (Marx et al., 2011, 2009). Mapped and modelled variations in trace element signatures and ratios of "far-travelled" sediment can elucidate shifts in dust sources and net transport (Marx and Kamber, 2010; Marx et al., 2011; Petherick et al., 2009). Grain size and morphology of quartz grains have also been analysed as proxies for wind speed and aeolian transport pathways (Stanley and De Deckker, 2002). The Aus2k data set contains two records that analyse the aeolian dust fraction in peat cores (Marx et al., 2009, 2011). In both records, cores were extracted from locations slightly elevated $(\sim 1 \mathrm{~m})$ in comparison to the surrounding bog. This collection approach is predicted to minimise transport of local sediment and maximise atmospheric deposition. Frozen sediment cores were sampled at multi-decadal resolution. Cores from both sites were examined for trace element concentration, which allowed for the reconstruction of overall dust deposition as a proxy for continental aridity, as well as contribution of dust from specific source areas (Marx and Kamber, 2010; Marx et al., 2005).
Pollen

Australasia has a rich history of palynological studies, with research extending back to the 1960s (Churchill, 1960; Moar, 1967). Early research focused on reconstructing vegetation diversity at a single site, but approaches have expanded to examine broader environmental questions such as regional vegetation response to climatic shifts (Donders et al., 2007), reconstruction of a specific variable across a region (Fletcher and Thomas, 2010a), recovery from episodes of disturbance such as fire (Lynch et al., 2007), and responses to human impacts in the pollen catchment (Haberle et al., 2006; Horrocks et al., 2001; Leahy et al., 2005).

The investigation of the abundance and ecological assemblage of pollen spores sheds lights on palaeoecological dynamics through time, predominantly driven by changes in climate (Donders et al., 2007; Kershaw et al., 1991) and the impacts by human activity (Lynch et al., 2007). There is an extensive network of well-studied sites centred on the Atherton Tablelands in northern Queensland (Haberle, 2005; Haberle et al., 2006; Kershaw, 1970, 1975, 1983, 1971; Kershaw et al., 2007; Walker et al., 2000), including some of the most highly cited records of AISM dynamics and rainforest response to climate variability through time (Kershaw, 1994). The majority of pollen records are restricted to the peripheries of the Australian continent due to the need for water availability in the accumulation and preservation of pollen grains (Fitzsimmons et al., 2013). There have been comparisons of available pollen records for southeast Australia (D'Costa and Kershaw, 1997) and a north-south transect of high-quality pollen records along the east coast of Australia (Donders et al., 2007). New Zealand palynology records cover the entire length of the country and range in resolution from millennial scale to multi-decadal scale (see references in Lorrey and Bostock, 2017).

While almost all Australasian pollen reconstructions are qualitative in their approach, there have been a small number of quantitative studies. Cook and Van der Kaars (2006) comprehensively outlined early approaches (i.e. single-taxa indicators and modern analogue techniques (MATs)) and their limitations in the Australian context. The same study explored the potential of existing pollen sites to be used for the construction of transfer functions and found that regional transfer functions could be used to associate modern pollen distributions with modern hydroclimate. Herbert and Harrison (2016) conducted a similar review of modern analogue techniques in Australia and suggested that, despite possible limitations in the current sampling density of the continent, MAT can be an appropriate reconstruction technique. Transfer functions have been produced for average annual temperature in Tasmania (Fletcher and Thomas, 2010a) and New Zealand (Wilmshurst et al., 2007), but no quantitative reconstructions that pass the Aus $2 \mathrm{k}$ criteria encompass the Common Era. Development of training data sets in New Zealand has historically been complicated by deforestation 
since $1200 \mathrm{CE}$; however, a pre-deforestation data set developed by Wilmshurst et al. (2007) mitigates this issue for future New Zealand studies.

\subsubsection{Marine cores}

Marine sediment cores have been collected from the entire perimeter of Australasia, some of which have accumulation rates and chronologies suited to the analysis of the last 2000 years (Figs. 1 and 3). In cores recovered in areas where sediment incorporates terrestrial input, microfossils reflect conditions within defined horizons in the water column, and organic biomarkers indicate environmental conditions in the biome of origin (Bradley, 2014). Marine sediments deposited within the last 2000 years are dated through radiocarbon methods and tephrochronology (Mohtadi et al., 2014; Oppo et al., 2009).

There is a dense concentration of marine cores in the Indonesian region, where there are large areas of shallow continental shelves (Reeves et al., 2013a). These areas remained above the lysocline through the recent past and now provide ideal sites for marine sediment core collection. Overwhelmingly the most commonly studied proxy in marine cores is the geochemistry of biogenic material. During recent millennia, oxygen isotopes of planktonic and benthic foraminifera vary as a function of both temperature and $\delta^{18} \mathrm{O}$ seawater ( $\mathrm{Za}$ chos et al., 1994). For some coupled ocean-atmosphere climate modes, such as ENSO and the IOD, the coupled warmwet and cold-dry conditions influence the $\delta^{18} \mathrm{O}$ signature in the same direction, thus intensifying the climate signal in the oxygen isotopes (Brijker et al., 2007; Khider et al., 2011).

In places where both temperature and salinity vary on inter-annual timescales, $\mathrm{Mg} / \mathrm{Ca}$ analyses allow for the elucidation of the two components of the $\delta^{18} \mathrm{O}$ signature. $\mathrm{Mg} / \mathrm{Ca}$ ratios are controlled by temperature and are independent of seawater salinity changes (Lea et al., 1999). These independent temperature determinations can then be used to remove the temperature component of $\delta^{18} \mathrm{O}$ and isolate the salinity component. Therefore, the water temperature and water salinity can be used independently for climate reconstructions (Elderfield and Ganssen, 2000). This has allowed the tracing of the geographic extent, dominant control, and average conditions of the Indo-Pacific Warm Pool through time (Oppo et al., 2009; Stott et al., 2004), as well as connectivity between the Pacific and Indian oceans through the Indonesian throughflow (Linsley et al., 2010; Newton et al., 2011). In addition, water-column dynamics have been investigated by reconstructing temperature differences between surfacedwelling and thermocline-dwelling species of foraminifera. This has led to inferences about wind-driven mixing (Steinke et al., 2010) and properties of water masses that upwell in other regions of the globe (Khider et al., 2014).

Alternate isotopic analyses, such as the $\delta \mathrm{D}$ interpretations outlined above, have also been applied to the marine realm (Tierney et al., 2010). In central Indonesia, one study has employed $\delta^{15} \mathrm{~N}$, controlled by basin ventilation, as a proxy for localised ENSO signatures (Langton et al., 2008). Marine proxies are well established as recorders of climate information over long timescales. Again, sedimentation rate is the primary limitation of marine cores as recorders of Common Era climate. It is also important to separate the atmospheric and oceanographic drivers of variability in sea-surface temperatures and salinity through multi-proxy approaches.

\subsubsection{Speleothems}

Over the past half-century, speleothems have emerged as valuable sources of palaeoclimate information because of their potential for preserving precisely dated, multi-proxy, high-resolution records of past climate change (Fairchild et al., 2006). They cover a range of temporal scales across the Holocene, from millennial (Partin et al., 2007) through to monthly to weekly resolution (Frappier et al., 2007; Treble et al., 2003, 2005a). Recent work indicates that Australasian speleothems offer a high-quality source of palaeoclimate information over the Common Era. Young speleothems (up to $\sim 300 \mathrm{yr}$ BP) can be dated through high-precision U-Th dating methods, as long as there is sufficient uranium within the calcium carbonate matrix and the growth rate is fast enough to provide sufficient material for dating (Zhao et al., $2009)$. Resulting dates can have appropriate precision $\left( \pm 10_{-}\right.$ 80 years) for reconstructing multi-decadal to centennial climate fluctuations (Zhao et al., 2009). Radiocarbon bombspike dating has also been used to date young speleothems when U-Th dating techniques are not appropriate (Hua et al., 2012).

Speleothems fill an important geographic niche in the Australasian region, particularly for Australia, as they can be found in karst regions where a lack of standing surface water precludes the development of lacustrine records. Similar to lake cores, geochemical interpretations are site-specific, with depositional controls varying with bedrock characteristics and local climate. Moreover, the application of multiple proxies contained within speleothems can be used to narrow the range of possible palaeoclimatic and palaeoenvironmental interpretations. The site-specific nature of many reconstructions is reliant on site monitoring, hydrologic modelling, and karst theory (Baker et al., 2014; Fischer and Treble, 2008).

The calcite mineralogy of speleothems means that they are ideal for oxygen and carbon isotope analysis and trace element concentration determinations. The complexity of sitespecific controls on oxygen and carbon isotopes is recognised within speleothem studies (Lachniet, 2009); as such, it is necessary to investigate the impact of precipitation geochemistry (Fischer and Treble, 2008), processes in the aerated (vadose) zone above the cave (Dreybrodt and Scholz, 2011), and in-cave conditions (Baldini et al., 2006) on the $\delta^{18} \mathrm{O}$ signal preserved in each speleothem. Oxygen isotopes in mid-latitude Australian speleothems primarily record rain- 
fall amount through precipitation isotopic composition (Treble et al., 2005a) or record karst aquifer recharge frequency (Markowska et al., 2016), whereas tropical samples from Indonesia and the monsoonal region of northern Australia are more sensitive to the intensity of precipitation (Denniston et al., 2013; Griffiths et al., 2013). Recent drip water monitoring has also identified a $\delta^{18} \mathrm{O}$ response signal after a bushfire, driven by a change in surface evaporation-precipitation balance (Nagra et al., 2016). In young speleothem records, $\delta^{18} \mathrm{O}$ values can be compared to instrumental climate data to identify correlations with temperature and rainfall (Treble et al., 2005a). Where speleothems can be sub-annually resolved, or where a significant seasonal bias can be inferred, excursions in speleothem $\delta^{18} \mathrm{O}$ in tropical regions can be related to past cyclone events; this signal has been used to calculate cyclone occurrence over the past millennium (Haig et al., 2014). Early- to mid-Holocene $\delta^{13} \mathrm{C}$ in a Tasmanian speleothem record was inferred to reflect productivity and the resulting carbon isotope fractionation in the soil (Xia et al., 2001). This is based on the extent to which atmospheric $\mathrm{CO}_{2}$ is released into the soil through vegetation breakdown and is controlled by moisture levels in the soil (Goede, 1994). The comparison of $\delta^{13} \mathrm{C}$ analyses with trace element analyses may provide clarification of dominant controls on carbon isotopic fractionate at a given study site (Treble et al., 2005b). Treble et al. (2005b) suggest that their 20th century $\delta^{13} \mathrm{C}$ record could partially reflect water stress on leaf stomata (Farquhar et al., 1988), based on correlation with $\mathrm{Mg}$ concentrations. In Indonesian speleothem records, $\delta^{13} \mathrm{C}$ has been found to often co-vary with $\mathrm{Mg} / \mathrm{Ca}$ and $\mathrm{Sr} / \mathrm{Ca}$ ratios, suggesting that these proxies respond to prior calcite precipitation (PCP; Griffiths et al., 2010; Partin et al., 2013). PCP occurs in dry conditions, when less water is transported or stored in the vadose zone, which leads to degassing of $\mathrm{CO}_{2}$ into fractures in the bedrock (Fairchild et al., 2000).

In the New Zealand setting, many different factors are demonstrated to influence stable isotope signals in speleothems (Williams et al., 2010). Previous studies, which are largely theoretical, have indicated that $\delta^{13} \mathrm{C}$ variations can be used to interpret climate changes in the form of local water balance (Lorrey et al., 2008). Including the aforementioned idiosyncrasies for cave environments and processes, local water balance has been largely assumed to represent effective precipitation in New Zealand. Therefore, past research has exploited $\delta^{13} \mathrm{C}$ as a proxy for hydroclimatic variability related to precipitation amount. That reasoning has been employed to make inferences from speleothems about regional atmospheric circulation, which controls climate regimes and regional-scale precipitation (Lorrey et al., 2007). This synoptic approach allows the integration of co-varying, spatially heterogeneous responses of several speleothem environments into surface climate, which is forced by orographic circulation and advection related to base climate state shifts (Lorrey et al., 2008, 2012, 2014).
In the Australian setting, $\mathrm{Mg} / \mathrm{Ca}$ in speleothems has been shown to be a reliable recorder of effective rainfall (Fairchild and Treble, 2009; Treble et al., 2003; McDonald et al., 2004) because longer water residence times increase the $\mathrm{Mg} / \mathrm{Ca}$ in speleothem drip water (Fairchild et al., 2000; Fairchild and McMillan, 2007). This relationship has been supported by comparison of recent speleothem records to instrumental data sets (Treble et al., 2003). In addition, Australian studies of $\mathrm{Sr} / \mathrm{Ca}$ have found the ratios to represent temperatureregulated fluctuations in terrestrial productivity above the cave (Desmarchelier et al., 2006) or the combined effect of PCP and/or growth rate, depending on the timescale examined (McDonald et al., 2004; Treble et al., 2003). Multiple nutrients in drip waters, including $\mathrm{Cl}, \mathrm{Mg}$, and $\mathrm{Sr}$, were impacted by bushfires in Western Australia, driven by removal by fire processes, and subsequent changes in surface evaporation (Nagra et al., 2016). Indonesian studies suggest that drip rate and residence time influence $\mathrm{Mg} / \mathrm{Ca}$ and $\mathrm{Sr} / \mathrm{Ca}$ ratios in locations where PCP is not a constant driver (Partin et al., 2013). P/Ca has been suggested to be a palaeorainfall proxy (Fairchild et al., 2001; Treble et al., 2003) because of the release of phosphorous from soils and subsequent transport and incorporation associated with heavy rainfall events.

The only speleothem record in the Aus $2 \mathrm{k}$ data set is from Liang Luar Cave, a tropical $\delta^{18} \mathrm{O}$ record that expresses precipitation intensity above the cave (Griffiths et al., 2016, 2009). The very fine sampling interval means that the average sample resolution is high ( 8 years sample $\left.{ }^{-1}\right)$.

\subsection{Discussion of age modelling approaches}

The recalibrated age-depth models developed in this study have variable agreement with the originally published models (Figs. 4 and S2). Most studies previously published in the Australasian region have constructed chronologies through linear interpolation between median calibrated ages. Blaauw (2010) stresses the hazard of ignoring the nonsingular age distribution of calibrated radiocarbon dates because of obscured error in the age-depth models when date distributions are not properly acknowledged. The Aus $2 \mathrm{k}$ records use variable construction methods for the published chronologies and variable methods of estimating and acknowledging errors. This is the primary reason for recalibrating existing Australasian age models and comparing the outcome of updated approaches to the published models.

Chronologies for most marine sediment cores are based on fitting a linear age-depth relationship across the set of dates. The results of bacon-derived age models moderately support the application of linear accumulation for this archive, with the ages of young and/or shallow samples more likely to match between the two approaches in comparison to samples from deeper in the core. The disparity between published and reconstructed ages for marine records increases back through time. This is most likely related to date density through individual cores, as well as periods of interpolation between 
dated horizons. Indonesian marine cores use the 1815 Tambora tephra as a chronological anchor, which decreases age uncertainty near the present, but date density further back in time varies between records.

The published Snowy Mountain core had age model difficulty, with two possible age models with similar $r^{2}$ values (Marx et al., 2011). The self-adjusting Monte Carlo approach within the bacon software clearly favoured one model over the other (Fig. S1). The bacon-derived age model showed greater agreement with the published age model built upon more dates. This is likely driven by acknowledgement of the probability distributions of calibrated radiocarbon dates, as well as estimated autoregression between sampled (but undated) depths.

Advances have been made with publicly accessible statistical age modelling software over the past decade. The "clam" (classical age modelling) software package facilitates age modelling through combining classical statistics with calibrated radiocarbon dates within a Monte Carlo framework (Blaauw, 2010). This approach incorporates realistic probability distributions for calibrated radiocarbon dates and can calculate age uncertainty through thousands of Monte Carlo iterations. However, the underlying statistical methods within and between classical and Bayesian approaches vary greatly (Blaauw, 2010; Blaauw and Christen, 2011; Bronk Ramsey, 2009). In the clam software, the creator chooses the type of relationship used to predict ages between chronological anchors (e.g. linear interpolation, polynomial regression, or smoothing splines), and then the program calculates likely age distributions based upon the chosen type of relationship. Blaauw (2010) suggests that Bayesian approaches construct more realistic age-depth models due to their incorporation of observed or predicted sediment behaviour; however, the simplicity of the classical approach means that it is arguably easier to construct age models, and the method remains transparent.

Two study sites in southern Australia (Barr et al., 2014) were originally published with chronologies constructed using clam. The Bayesian age models, based on the same radiocarbon and ${ }^{210} \mathrm{~Pb}$ dates, produced similar maximum and minimum ages and timing of events within the record; however, notable differences are also visible, particularly for the Lake Elingamite record between 100 and $50 \mathrm{Y} \mathrm{BP}$ and between 1300 and 1200 Y BP (Fig. S2). Differing age-depth model behaviour within these periods generally reflects differences in the degree of rigidity in the modelling approaches. That is, bacon age models appear more resistant to shifts in accumulation rate, even when low memory strength is implied within the prior settings. By contrast, clam allows the user to fit age models that respond more readily to changes in sediment accumulation rate. Rigidity is not a benefit or weakness of any given approach, but is a characteristic to be considered during age model construction. The literature suggests that Bayesian approaches still incorporate more site-specific information than classical methods; however, consistency in determining age uncertainties and objectivity in age modelling is arguably more important for regional comparisons (Blaauw, 2010).

The strongest predictors for the error envelope at the oldest or $1 \mathrm{CE}$ sample are (i) the distance between the oldest or $1 \mathrm{CE}$ sample depth and the nearest age anchor, and (ii) the $95 \%$ confidence interval at the nearest dated horizon. The records that have the greatest departure from the published age models are those that have the smallest number of chronological anchors. The international PAGES working group established a criterion of two dates for records $<1000$ years and three dates for records between 1000 and 2000 years in length. However, the outcomes of this study demonstrate that this criterion is still too relaxed for robust investigation of decadal to multi-decadal climate variability in the Common Era. For example, the age model for one Makassar Strait record (Tierney et al., 2010) is based on six dates and one tephra layer across two cores covering the past 2000 years. The number of dates present is much higher than that suggested by PAGES2k, but dating density in this record still results in an average $95 \%$ confidence envelope for sample ages that is greater than 100 years. Therefore, the outcome of age model recalibration in this study suggests that the criterion of two or three dates within 2000 years is not nearly stringent enough to provide robust chronologies for examining climate dynamics over sub-centennial timescales. Based on the outcomes presented here, the authors propose at least one date every 200 years, with at least one date near the top of the core, and another near the oldest sample or $1 \mathrm{CE}$.

It can be argued that the Bayesian methods applied in this study represent the current state of the science with regards to age-depth modelling of Quaternary sediment sequences. Nevertheless, due to the ongoing development of radiocarbon calibration and modelling techniques, the age models generated here should not be viewed as permanent optimised chronologies. Radiocarbon calibration and chronology construction methods are likely to improve through time. Therefore, continuous updates of age modelling approaches could be assisted via provision of raw dates and complete chronological metadata in publications and public data repositories.

\subsection{Aus2k data set limitations, potential, and recommendations}

Identification and assessment of existing Australasian palaeoclimate records have highlighted limitations in the current data network. These constraints are outlined and discussed in the following section. This review also highlights additional action items that may be undertaken to improve the data network in the Australasian region. Expansion of the Aus2k palaeoclimate data network in a geographically large but institutionally limited region is a considerable undertaking. Therefore, a concerted community effort is required to coordinate the collection of new palaeoclimate data. 


\subsubsection{Climate variables and relationships}

One reason for identifying and assessing low-resolution records in Australasia is to determine what climate variables are represented in the high-quality subset. A distinct skew is evident for the types of climate variables currently available. New Zealand is biased towards temperature interpretations, with many of the existing low-frequency records having been constructed through multi-decadal binning of annual data (not discussed within this study). Conversely, climate variables currently represented in the high-quality Aus $2 \mathrm{k}$ subset are heavily skewed towards hydroclimate indicators, as reconstructed by the diverse proxies outlined in Sect. 4.1.

Only one low-resolution terrestrial temperature reconstruction exists in the Aus2k data set: the Duckhole Lake record (Saunders et al., 2013). A range of proxies have been used in other regions of the world to reconstruct terrestrial palaeotemperatures in low-resolution records (Marcott et al., 2013); however, they have not yet been applied to Australasian sites on the timescales examined here. Lake temperatures have been reconstructed through chironomid transfer functions on the east coast of Australia (Chang et al., 2015), Tasmania (Rees and Cwynar, 2010) and the South Island of New Zealand (Vandergoes et al., 2008; Woodward and Shulmeister, 2007) on timescales beyond the Common Era. Modern training sets exist for additional locations in Tasmania (Rees et al., 2008) and an additional location on the South Island, New Zealand (Dieffenbacher-Krall et al., 2007). All of these transfer functions have the potential of being applied to the Common Era, thus providing quantitative reconstructions from subtropical and temperature climate zones of Australasia.

Another temperature proxy applied to Australasian sites is the distribution of branched glycerol dialkyl glycerol tetraethers (GDGTs) in membrane lipids in sediments (Prahl and Wakeham, 1987). This proxy has been used to reconstruct mean annual temperature in Lake Pupuke in New Zealand (Heyng et al., 2015) and Lake Mackenzie in Australia (Woltering et al., 2014). Both temperature and aridity have been reconstructed for Onepoto maar by combining analysis of fatty acid $\delta^{13} \mathrm{C}$, biomass-burning biomarkers, and pollen abundances calibrated to mean annual temperatures (Sikes et al., 2013). The use of GDGTs and other lipid biomarkers has great potential for reconstructing Australasian temperatures during the Common Era; however, it faces significant challenges too, including non-systematic uncertainties of $\sim 1^{\circ} \mathrm{C}$, which may obscure the magnitude of temperature change during the last 2000 years, in addition to much greater systematic uncertainties related to the origin of the biomarkers and the type of calibration used (Woltering et al., 2014).

Borehole-derived ground surface temperature reconstructions from across the Australian continent show strong agreement with high-resolution palaeoclimate data sets (Appleyard, 2005; Cull, 1982; Huang et al., 2000; Pollack et al., 2006; Suman et al., 2016). However, the temperature estimates derived from boreholes reflect long-term, lowfrequency trends that fall outside the desired sample resolution of this study (Pollack et al., 2006).

A requirement of all palaeoclimate research is a thorough understanding of the relationship between climate variability and the geochemical, sedimentological, or biological composition of any record. To address these questions, researchers are employing long-term monitoring strategies to develop a detailed understanding of the local conditions required for calibrating palaeoclimate archives (Markowska et al., 2016; Treble et al., 2003). In some cases, monitoring outcomes can lead to some palaeoclimate records being excluded on the basis of hitherto unknown complications; conversely, modelling the response of palaeoclimate tracers to climate change can lead to more rigorous quantitative constraints on past climates (Jones et al., 1998, 2001). Developing modern monitoring strategies should sit prominently in the collective community goal of generating more reliable regional palaeoclimate records. Site-specific monitoring projects are particularly important in the Australian region, where shortcomings in the gridded instrumental meteorological data set are observed in rural areas and areas of steep climatic gradients (Jones et al., 2009; Tait et al., 2006).

\subsubsection{Chronology}

The most important characteristic that a record must possess for inclusion in the high-quality data set is a robust chronology, accompanied by acknowledgement and estimation of possible sources of uncertainty. Many older publications have a small number of dates due to the high cost of radiocarbon analysis in past decades. There are now lowcost commercial services, and institutional dating operations have endeavoured to match the costs of the competitive commercial market. These developments mean new, more costeffective dating strategies can be employed to create new well-dated records, as well as renewed efforts to revisit former sites to improve the original chronologies.

There are also important caveats with composite records that cover the last 2000 years (see speleothem data presented in Lorrey et al., 2008). For example, composite data may be subject to distortion because of inconsistencies in the methods used to compile overlapping series into a longer, continuous record. From this perspective, potential issues could be inherited from changes in the sampling interval, as well as resultant mean and variance shifts across transitions in which individual series are spliced into longer records (Lorrey et al., 2010). A similar perspective can also be applied to irregular event-based records, such as alluvial sediments (Grant, 1985) that are bracketed by tephras and/or radiocarbon ages, or compilations of geochronology dates on moraine emplacement. In these types of cases, further work could help to evaluate the veracity of composite low-resolution records and also determine protocols on how the development and in- 
terpretation of "master records" (e.g. isotope chronologies from several speleothems in one cave) could be improved. Inevitably, a multi-proxy approach for corroborating interpretations is warranted.

It is possible for local factors to limit optimal dating materials or complicate the interpretation of radiocarbon dates (e.g. Rodysill et al., 2013) However, use of tephrostratigraphy as chronological has commonly been applied in New Zealand records (Lowe et al., 2013), has been employed in initial syntheses (Lorrey et al., 2008, 2010), and has equivalent potential in most Malay Archipelago records. The only eruption used as an anchor in the Aus2k data set is Tambora (1815 CE) in the Malay Archipelago records. Additional New Zealand tephras have been identified and characterised within the Common Era (Lowe et al., 2013), and a previously unutilised tephra in the Malay Archipelago has been characterised (Alloway et al., 2017). Identification of additional eruptions, even in the form of cryptotephra (nonvisible tephra layers), is a potential source of chronological tie points where datable material for radiocarbon analyses can be scarce (Gehrels et al., 2006, 2008). For example, the discovery of both basaltic and silicic glass shards in the Holocene sediments of Lake Keilambete, Victoria, highlights the potential of using cryptotephra to constrain chronologies and correlate records across southeastern Australia and potentially between Australia and New Zealand (Smith et al., 2016).

When possible, conducting core-top radionuclide analyses, such as ${ }^{210} \mathrm{~Pb}$ and ${ }^{137} \mathrm{Cs}$ (Appleby and Oldfield, 1978) can offer greater confidence in the age at the top of the core, as well as any significant impacts on the site by the arrival of Europeans (Sloss et al., 2011; Rodysill et al., 2013; Roop et al., 2016). A robust "young" chronology derived from the most recent section of cores may also allow comparison of lower-resolution records to instrumental observations for quantitative calibration. Future work on geochronology best practice for the Aus2k region will help to define relevant protocols and establish potential chronological tie points.

\subsubsection{Climate teleconnections}

Previously, annually resolved palaeoclimate records from one location within the Australasian region have demonstrated statistically significant relationships with climatic conditions at distant locations within the same geographic area (Gallant and Gergis, 2011; Gergis et al., 2012; Ho et al., 2013). These climate teleconnections have been utilised to expand spatial coverage of palaeoclimate reconstructions within Australasia (Ho et al., 2013). However, recent modelling and examination of documentary evidence have indicated that the climate teleconnection between Australian climate and remote drivers, such as temperatures in the western Pacific Ocean, have varied on multi-decadal to centennial timescales (Ashcroft et al., 2016; Brown et al., 2016; Hope et al., 2016; Lewis and LeGrande, 2015).
Multiple approaches for integrating Australasian palaeoclimate data have recognised the importance of teleconnection stability and how varying teleconnection strength through time may impact reconstruction interpretations (Gergis et al., 2012; Gallant et al., 2013; Goodwin et al., 2013, 2014; Lorrey et al., 2014; Gergis et al., 2016). All of the approaches are potentially limited by the short length and quality of calibration timescales, uncertainties in proxy archive dating, regional biases from uneven spatial coverage, seasonal sensitivity, and in some cases multiple influences on proxy archive interpretation (i.e. potential distortion effects from other environmental processes). One principal component regression (PCR) ensemble method uses Monte Carlo simulations of analytical parameters such as principal component truncation, proxy selection, and variations in the length of calibration and/or the verification interval to estimate reconstruction uncertainty. The ensemble spread of possible outcomes is then used as a quantitative estimate of uncertainty, which may contain a component of variability related to teleconnection instability (Gergis et al., 2012, 2016).

Another approach has applied atmospheric regimes in order to avoid climate proxy teleconnection dependencies (Kidson, 2000; Lorrey et al., 2007; Goodwin et al., 2013). Emphasis is placed on maximising agreement between locally derived palaeoclimate signals that are influenced by physical factors such as site-specific orography, advection, and wind stress. In that situation, local climates are assumed to respond consistently through time to synoptic-scale atmospheric circulation. In the absence of other main forcing mechanisms like volcanism, solar variability, greenhouse gases, and insolation changes, atmospheric regime frequency shifts are implicated for causing local anomalies (Goodwin et al., 2013; Jiang et al., 2013; Lorrey et al., 2007, 2008, 2014; Lorrey et al., 2010). Past climate interpretations using this approach remain heavily reliant on modern observations, palaeoclimate reconstructions that have been calibrated to local climate data, sufficient palaeodata network density, and understanding how other forcing mechanisms operated and impacted local climates in the past.

One high-quality record located on the South Island of New Zealand indicates that dust accumulation in a peat bog may be used as a proxy for aridity on the Australian continent (Marx et al., 2009). This interpretation has been supported by modern (1989-2001) dust provenance identification through trace element signatures (Gingele et al., 2007; Marx et al., 2005; McGowan et al., 2005). In that case, a physical process (represented by a unique dust signature) supports a plausible link to a direct, long-distance, synoptically driven transport process and, therefore, a dynamical association with remote climate forcing.

The use of upstream sites could assist in improving the skill of reconstructions for a particular proxy at locations of interest. The utilisation of high-quality sites near to, but outside, the location of interest may lead to regional reconstructions with higher statistical skill, as they may preserve sig- 
nals of large-scale circulation patterns rather than local climate features (Gallant and Gergis, 2011; Gergis et al., 2012, 2016; Ho et al., 2013). In Australia, sites along the southern coast of South Australia and Victoria are impacted by a similar atmospheric circulation features and remote climate drivers as major cities and agricultural centres of southern Australia (Murphy and Timbal, 2008), lending the potential to use palaeoclimate records from near the coast to infer patterns of change inland (Ho et al., 2013).

Overall, the diversity of reconstruction methods applied to the Australian region, which either do or do not estimate uncertainty associated with teleconnection instability, provides opportunities to test and compare methods, examine reconstruction assumptions, and reconstruct climate for areas where there may be limited opportunities for data collection. The fact that many of these approaches result in the generation of spatial fields means that there is potential to utilise their collective outputs as an ensemble, forward model, or as prospecting guidance to target and collect new records in Australasia. In particular, the resulting spatial fields and climate metrics (indices, archetypal patterns) that are able to be generated from the current range of approaches used by the Aus2k group have offered opportunities to explain how local signals in a regional palaeoclimate network simultaneously arise in a dynamical context. In many cases, the different approaches have been used as tools to explore hypotheses and reconcile apparently conflicting climate signals (spatial heterogeneity) in the Southern Hemisphere data network (Goodwin et al., 2013, 2014; Lorrey et al., 2013, 2007, 2008).

Finally, the approaches employed thus far demonstrate potential for upscaling local palaeoclimate data assemblages to be more comparable with global climate model simulations (Ackerley et al., 2011; Lorrey et al., 2012). A recent highresolution reconstruction of Australian temperature over the last millennium demonstrates the regionally specific timing and magnitude of temperature fluctuations that can be directly compared to climate model simulations to determine dynamical influences (see studies listed in Sect. 4a of Gergis et al., 2016). Overall, understanding of regional climate variability is important for using palaeoclimate data to evaluate possible responses to future climate change.

\subsubsection{Recommendations}

The following recommendations for future low-resolution palaeoclimate research of the Common Era are provided to help improve the coverage and quality of the Australasian data network:

1. The primary difficulty in establishing a basis for data comparison is a lack of publicly available data. Although there are multiple public data archives available (e.g. NOAA National Centers for Environmental Information, PANGAEA, Neotoma), few low-resolution records from Australasia are formally archived. It is of vital importance for the continuation of data comparison in climate research that those creating records archive their existing and future data with at least one of those repositories. Future application and comparison of published data would benefit from additional metadata included in publications. Useful metadata fields include raw geochronological data, archive collection dates, sampling interval, temporal resolution, and the method (and data) by which the proxy-climate relationship has been established.

2. Site monitoring (Treble et al., 2013; Roop et al., 2015; Tibby et al., 2003), climate sensitivity studies (Bertrand et al., 2002; Neukom and Gergis, 2012), and proxy systems models (Dee et al., 2016; Evans et al., 2013) are approaches that increase confidence in the type and strength of climate signal expressed by a proxy. These approaches would also help to improve the interpretation of previously published work in Australasia. Site monitoring and the development of transfer functions to help develop frameworks for dynamical interpretation would also improve the quality of mechanistic models and quantitative climate reconstructions. Support for the augmentation of global reanalysis data sets (i.e. 20CR) (Compo et al., 2011) via data rescue activities (Atmospheric Circulation Reconstructions over the Earth, OldWeather, etc.) (Allan et al., 2011, 2016; Brohan et al., 2012) to extend calibration series would provide large benefits to the palaeoclimate research community. Comprehensive understanding of site-specific climate-proxy relationships strengthens confidence that palaeoclimate records are expressing climate variability through time without modification of signals by human activities in the catchment.

3. Robust chronologies are of the utmost importance in understanding the frequency of climate fluctuations, defining the timing of events, and testing for synchronicity of events between sites. These questions cannot be confidently answered without rigorous chronological control. Reliable chronologies require multiple dates within the past 2000 years, a date near the top and bottom of the core or near $1 \mathrm{CE}$, and sufficient density of dates (at least one date per 200 years) across the Common Era to identify possible changes in timing within the past $\sim 2000$ years. Furthermore, although the use of cryptotephra to correlate sedimentary records has rapidly developed over the last decade, its application to Australasian (particularly Australian) records has been notably slow to take off, despite considerable potential for constraining chronologies for the last 2000 years (Davies, 2015; Smith et al., 2016). Generation of the Bayesian age models presented here suggests that classical statistics (i.e. linear interpolation or spline smoothing) might not fully capture complex depositional pattern changes in the Australasian region. 


\section{Conclusions}

Within this study, 675 non-annually resolved palaeoclimate records across the Australasian region were identified and assessed. Of these, the majority are sediment cores from lakes and wetlands, with pollen ecological assemblages and invertebrate fossil geochemistry as the most common proxies. Of the large number of records identified, a subset of only 22 records met the international PAGES2k selection criteria to be classified as high-quality records. This data set contains good examples of what characteristics are necessary for the investigation of climate variability during the Common Era. Additional records of similar quality are needed to further expand the spatial coverage and diversity of climate variables within the Aus $2 \mathrm{k}$ record network.

For each of the 22 records that were identified in this study, new age-depth models were constructed using the consistent Bayesian age modelling approach. Comparison between published and bacon-derived age models suggests that age modelling has a strong influence on the timing of events within and between records. Overall, three recommendations are presented to improve the quality of future low-resolution climate reconstructions and syntheses. Public availability of data and metadata will facilitate record comparison, updates, and assessment. Thorough characterisation of proxyclimate relationships could be achieved through site monitoring, climate signal characterisation through model comparison, and development and evaluation of new biologicalsedimentological transfer functions. Finally, chronologies must be greatly improved for confident characterisation of Common Era climate variability. Increased numbers of dates, core-top dating, incorporation of sediment behaviour and site idiosyncrasies in age-depth model construction, and acknowledgement of age uncertainties are necessary.

The relatively low number of high-quality, low-resolution records in comparison with other regions of the world highlights the progress that is needed to improve reconstructions of the climate of the past 2000 years in Australasia. However, the existing high-quality records demonstrate the potential of sites within this region to provide well-dated records with recognised connections to climate variables. In addition, a range of reconstruction techniques applied to other regions and timescales have the potential to expand the spatial coverage and range of climate variables in Australasia.

Data availability. Originally published and bacon-derived recalibrated age-depth models can be found in the NOAA palaeoclimate archive (ftp://ftp.ncdc.noaa.gov/pub/data/paleo/pages $2 \mathrm{k} /$ dixon2017australasia/, NOAA, 2017).

The Supplement related to this article is available online at https://doi.org/10.5194/cp-13-1403-2017-supplement.
Author contributions. BCD identified and assessed the Australian and Malay Archipelago palaeoclimate records and wrote the paper with the assistance of JJT, who conducted the initial database collation. AML identified and assessed the New Zealand records. IDG oversaw the construction of the joint report between Macquarie University and the New South Wales Department of Environment, Climate Change, and Water, which was the inspiration and a major data source for this paper. JG instigated and directed the initial stages of the Aus2k low-resolution data initiative. All co-authors contributed to discussion of the content and the writing of the paper.

Competing interests. The authors declare that they have no conflict of interest.

Special issue statement. This article is part of the special issue "Climate of the past 2000 years: regional and trans-regional syntheses". It is not associated with a conference.

Acknowledgements. This is a contribution to the Past Global Changes (PAGES) 2k Network through the Aus2k working group. PAGES is supported by the US and Swiss National Science Foundations. Bronwyn C. Dixon was supported by an Australian Postgraduate Award and an Australian Institute of Nuclear Science and Engineering (AINSE) postgraduate award. Jonathan J. Tyler was supported by a Collaborative Research Network (CRN) fellowship and the Adelaide University Environment Institute. Andrew M. Lorrey's contribution was supported by the NIWA corefunded project "Climate Present and Past" contract CAOA1701. Joëlle Gergis was funded by Australian Research Council project DE130100668. The authors wish to thank all record creators and members of the Australasian Quaternary Association who contributed data and information to this project.

Edited by: Raphael Neukom

Reviewed by: two anonymous referees

\section{References}

Ackerley, D., Lorrey, A., Renwick, J. A., Phipps, S. J., Wagner, S., Dean, S., Singarayer, J., Valdes, P., Abe-Ouchi, A., Ohgaito, R., and Jones, J. M.: Using synoptic type analysis to understand New Zealand climate during the Mid-Holocene, Clim. Past, 7, 11891207, https://doi.org/10.5194/cp-7-1189-2011, 2011.

Adrian, R., O'Reilly, C. M., Zagarese, H., Baines, S. B., Hessen, D. O., Keller, W., Livingstone, D. M., Sommaruga, R., Straile, D., Van Donk, E., Weyhenmeyer, G. A., and Winder, M.: Lakes as sentinels of climate change, Limnol. Oceanogr., 54, 2283-2297, https://doi.org/10.4319/lo.2009.54.6_part_2.2283, 2009.

Allan, R., Brohan, P., Compo, G. P., Stone, R., Luterbacher, J., and Brönnimann, S.: The international atmospheric circulation reconstructions over the earth (ACRE) initiative, B. Am. Meteorol. Soc., 92, 1421-1425, 2011. 
Allan, R., Endfield, G., Damodaran, V., Adamson, G., Hannaford, M., Carroll, F., Macdonald, N., Groom, N., Jones, J., Williamson, F., Hendy, E., Holper, P., Arroyo-Mora, J. P., Hughes, L., Bickers, R., and Bliuc, A.-M.: Toward integrated historical climate research: the example of atmospheric circulation reconstructions over the Earth, WIRES Clim. Change, 7, 164174, https://doi.org/10.1002/wcc.379, 2016.

Alloway, B. V., Lowe, D. J., Barrell, D. J. A., Newnham, R. M., Almond, P. C., Augustinus, P. C., Bertler, N. A. N., Carter, L., Litchfield, N. J., McGlone, M. S., Shulmeister, J., Vandergoes, M. J., Williams, P. W., and Members, N. I.: Towards a climate event stratigraphy for New Zealand over the past 30000 years (NZ-INTIMATE project), J. Quaternary Sci., 22, 9-35, https://doi.org/10.1002/jqs.1079, 2007.

Alloway, B. V., Andreastuti, S., Setiawan, R., Miksic, J., and Hua, Q.: Archaeological implications of a widespread 13th century tephra marker across the central Indonesian Archipelago, Quaternary Sci. Rev., 155, 86-99, https://doi.org/10.1016/j.quascirev.2016.11.020, 2017.

Anchukaitis, K. J. and Tierney, J. E.: Identifying coherent spatiotemporal modes in time-uncertain proxy paleoclimate records, Clim. Dynam., 41, 1291-1306, https://doi.org/10.1007/s00382012-1483-0, 2012.

Appleby, P. G. and Oldfield, F.: The calculation of lead-210 dates assuming a constant rate of supply of unsupported ${ }^{210} \mathrm{~Pb}$ to the sediment, Catena, 5, 1-8, https://doi.org/10.1016/S03418162(78)80002-2, 1978.

Appleyard, S. J.: Late Holocene temperature record from southwestern Australia: evidence of global warming from deep boreholes, Aust. J. Earth Sci., 52, 161-166, https://doi.org/10.1080/08120090500100028, 2005.

Ashcroft, L., Gergis, J., and Karoly, D. J.: Long-term stationarity of El Niño-Southern oscillation teleconnections in southeastern Australia, Clim. Dynam., 46, 2991-3006, https://doi.org/10.1007/s00382-015-2746-3, 2016.

Baker, A. J., Mattey, D. P., and Baldini, J. U. L.: Reconstructing modern stalagmite growth from cave monitoring, local meteorology, and experimental measurements of dripwater films, Earth Planet. Sc. Lett., 392, 239-249, https://doi.org/10.1016/j.epsl.2014.02.036, 2014.

Baldini, J. U. L., McDermott, F., and Fairchild, I. J.: Spatial variability in cave drip water hydrochemistry: implications for stalagmite paleoclimate records, Chem. Geol., 235, 390-404, https://doi.org/10.1016/j.chemgeo.2006.08.005, 2006.

Barber, K. E., Chambers, F. M., Maddy, D., Stoneman, R., and Brew, J. S.: A sensitive high-resolution record of late Holocene climatic change from a raised bog in northern England, Holocene, 4, 198-205, https://doi.org/10.1177/095968369400400209, 1994.

Barr, C.: Droughts and flooding rains: a fine-resolution reconstruction of climatic variability in western Victoria, Australia, over the last 1500 years, geographical and environmental studies, $\mathrm{PhD}$, University of Adelaide, Adelaide, 406 pp., 2010.

Barr, C., Tibby, J., Gell, P., Tyler, J., Zawadzki, A., and Jacobsen, G. E.: Climate variability in south-eastern Australia over the last 1500 years inferred from the high-resolution diatom records of two crater lakes, Quaternary Sci. Rev., 95, 115-131, https://doi.org/10.1016/j.quascirev.2014.05.001, 2014a.
Barr, C., Tibby, J., Gell, P., Tyler, J. J., Zawadzki, A., and Jacobson, G. E.: Southeast Australia 1500 year crater lake salinity reconstructions, available at: https://www.ncdc.noaa.gov/paleo/study/ 22432 (last access: 17 October 2017), 2014b.

Barrell, D. J. A., Almond, P. C., Vandergoes, M. J., Lowe, D. J., Newnham, R. M., and Members, I.: A composite pollenbased stratotype for inter-regional evaluation of climatic events in New Zealand over the past 30000 years (NZINTIMATE project), Quaternary Sci. Rev., 74, 4-20, https://doi.org/10.1016/j.quascirev.2013.04.002, 2013.

Beavan-Athfield, N. and Sparks, R. J.: Dating of rattus exulans and bird bone from Pleasant River (Otago, New Zealand): radiocarbon anomalies from diet, J. Roy. Soc. New Zeal., 31, 801-809, 2001.

Bertrand, C., Loutre, M. F., Crucifix, M., and Berger, A.: Climate of the last millennium: a sensitivity study, Tellus A, 54, 221-244, https://doi.org/10.1034/j.1600-0870.2002.00287.x, 2002.

Bickford, S. and Gell, P.: Holocene vegetation change, Aboriginal wetland use and the impact of European settlement on the Fleurieu Peninsula, South Australia, Holocene, 15, 200-215, https://doi.org/10.1191/0959683605hl800rp, 2005.

Blaauw, M.: Methods and code for "classical" age-modelling of radiocarbon sequences, Quat. Geochronol., 5, 512-518, https://doi.org/10.1016/j.quageo.2010.01.002, 2010.

Blaauw, M. and Christen, J. A.: Flexible paleoclimate age-depth models using an autoregressive gamma process, Bayesian Anal., 6, 457-474, https://doi.org/10.1214/11-ba618, 2011.

Black, M. P., Mooney, S. D., and Haberle, S. G.: The fire, human and climate nexus in the Sydney Basin, eastern Australia, Holocene, 17, 469-480, https://doi.org/10.1177/0959683607077024, 2007.

Blois, J. L., Williams, J. W., Grimm, E. C., Jackson, S. T., and Graham, R. W.: A methodological framework for assessing and reducing temporal uncertainty in paleovegetation mapping from late-Quaternary pollen records, Quaternary Sci. Rev., 30, 19261939, https://doi.org/10.1016/j.quascirev.2011.04.017, 2011.

Booth, R. K., Jackson, S. T., and Notaro, M.: Using peatland archives to test paleoclimate hypotheses, PAGES (Past Global Changes) News, 18, 6-8, 2010.

Bostock, H. C., Barrows, T. T., Carter, L., Chase, Z., Cortese, G., Dunbar, G. B., Ellwood, M., Hayward, B., Howard, W., Neil, H. L., Noble, T. L., Mackintosh, A., Moss, P. T., Moy, A. D., White, D., Williams, M. J. M., and Armand, L. K.: A review of the Australian-New Zealand sector of the Southern Ocean over the last $30 \mathrm{ka}$ (Aus-INTIMATE project), Quaternary Sci. Rev., 74, 35-57, https://doi.org/10.1016/j.quascirev.2012.07.018, 2013.

Bowler, J. M.: Aridity in Australia - age, origins, and expression in aeolian landforms and sediments, Earth-Sci. Rev., 12, 279-310, https://doi.org/10.1016/0012-8252(76)90008-8, 1976.

Bowler, J. M.: Australian salt lakes - a paleohydrologic approach, Hydrobiologia, 81-2, 431-444, https://doi.org/10.1007/bf00048730, 1981.

Bowler, J. M. and Hamada, T.: Late Quaternary stratigraphy and radiocarbon chronology of water level fluctuations in Lake Keilambete, Victoria, Nature, 232, 330-332, https://doi.org/10.1038/232330a0, 1971. 
Bradley, R. S.: Paleoclimatology: Reconstructing Climates of the Quaternary, 3 Edition, Academic Press, Amsterdam, 696 pp., 2014.

Brijker, J. M., Jung, S. J. A., Ganssen, G. M., Bickert, T., and Kroon, D.: ENSO related decadal scale climate variability from the Indo-Pacific Warm Pool, Earth Planet. Sc. Lett., 253, 67-82, https://doi.org/10.1016/j.eps1.2006.10.017, 2007.

Brohan, P., Allan, R., Freeman, E., Wheeler, D., Wilkinson, C., and Williamson, F.: Constraining the temperature history of the past millennium using early instrumental observations, Clim. Past, 8, 1551-1563, https://doi.org/10.5194/cp-8-1551-2012, 2012.

Bronk Ramsey, C.: Bayesian analysis of radiocarbon dates, Radiocarbon, 51, 337-360, 2009.

Brown, J. R., Hope, P., Gergis, J., and Henley, B. J.: ENSO teleconnections with Australian rainfall in coupled model simulations of the last millennium, Clim. Dynam., 47, 79-93, https://doi.org/10.1007/s00382-015-2824-6, 2016.

Burrows, M. A., Fenner, J., and Haberle, S. G.: Humification in northeast Australia: dating millennial and centennial scale climate variability in the late Holocene, Holocene, 24, 1707-1718, https://doi.org/10.1177/0959683614551216, 2014.

Chang, J. C., Shulmeister, J., Woodward, C., Steinberger, L., Tibby, J., and Barr, C.: A chironomid-inferred summer temperature reconstruction from subtropical Australia during the last glacial maximum (LGM) and the last deglaciation, Quaternary Sci. Rev., 122, 282-292, https://doi.org/10.1016/j.quascirev.2015.06.006, 2015.

Chen, Z. H. and Grasby, S. E.: Impact of decadal and century-scale oscillations on hydroclimate trend analyses, J. Hydrol., 365, 122-133, https://doi.org/10.1016/j.jhydrol.2008.11.031, 2009.

Chester, P. I. and Prior, C. A.: An AMS C-14 pollen-dated sediment and pollen sequence from the late holocene, southern coastal Hawke's Bay, New Zealand, Radiocarbon, 46, 721-731, 2004.

Chivas, A. R., De Deckker, P., and Shelley, J. M. G.: Strontium content of ostracods indicates lacustrine paleosalinity, Nature, 316, 251-253, https://doi.org/10.1038/316251a0, 1985.

Chivas, A. R., Dedeckker, P., and Shelley, J. M. G.: Magnesium and Strontium in nonmarine ostracod shells as indicators of paleosalinity and paleotemperature, Hydrobiologia, 143, 135-142, https://doi.org/10.1007/bf00026656, 1986.

Churchill, D. M.: Late quaternary changes in the vegetation on Rottnest Island, West Australian Nat., 7, 160-166, 1960.

Compo, G. P., Whitaker, J. S., Sardeshmukh, P. D., Matsui, N., Allan, R. J., Yin, X., Gleason, B. E., Vose, R. S., Rutledge, G., Bessemoulin, P., Brönnimann, S., Brunet, M., Crouthamel, R. I., Grant, A. N., Groisman, P. Y., Jones, P. D., Kruk, M. C., Kruger, A. C., Marshall, G. J., Maugeri, M., Mok, H. Y., Nordli, Ø., Ross, T. F., Trigo, R. M., Wang, X. L., Woodruff, S. D., and Worley, S. J.: The twentieth century reanalysis project, Q. J. Roy. Meteor. Soc., 137, 1-28, https://doi.org/10.1002/qj.776, 2011.

Cook, E. J. and Van der Kaars, S.: Development and testing of transfer functions for generating quantitative climatic estimates from Australian pollen data, J. Quat. Sci., 21, 723-733, https://doi.org/10.1002/jqs.1076, 2006.

Cook, E. R., Briffa, K. R., and Jones, P. D.: Spatial regression methods in dendroclimatology - a review and comparison of 2 techniques, Int. J. Climatol., 14, 379-402, https://doi.org/10.1002/joc.3370140404, 1994.
Cook, E. R., Briffa, K. R., Meko, D. M., Graybill, D. A., and Funkhouser, G.: The segment length curse in long tree-ring chronology development for paleoclimatic studies, Holocene, 5, 229-237, https://doi.org/10.1177/095968369500500211, 1995.

Crausbay, S. D., Russell, J. M., and Schnurrenberger, D. W.: A ca. 800 year lithologic record of drought from sub-annually laminated lake sediment, East Java, J. Paleolimnol., 35, 641-659, https://doi.org/10.1007/s10933-005-4440-7, 2006a.

Crausbay, S. D., Russell, J. M., and Schnurrenberger, D. W.: Ranu Lamongan, East Java, Indonesia, 800 year drought index, available at: https://www.ncdc.noaa.gov/paleo/study/22409 (last access: 17 October 2017), 2006 b.

Cull, J. P.: An appraisal of Australian heat-flow data, Bmr. J. Aust. Geol. Geop., 7, 11-21, 1982.

Davies, S. M.: Cryptotephras: the revolution in correlation and precision dating, J. Quaternary Sci., 30, 114-130, https://doi.org/10.1002/jqs.2766, 2015.

D'Costa, D. and Kershaw, A. P.: An expanded recent pollen database from south-eastern Australia and its potential for refinement of palaeoclimatic estimates, Aust. J. Bot., 45, 583-605, https://doi.org/10.1071/bt96046, 1997.

De Deckker, P.: Holocene ostracods, other invertebrates and fish remains from cores of four maar lakes in southeastern Australia, Proceedings of the Royal Society of Victoria, 94, 183-220, 1982.

De Deckker, P., Chivas, A. R., and Shelley, J. M. G.: Uptake of $\mathrm{Mg}$ and $\mathrm{Sr}$ in the euryhaline ostracod Cyprideis determined from in vitro experiments, Paleogeogr. Paleoclimatol. Paleoecol., 148, 105-116, https://doi.org/10.1016/s0031-0182(98)00178-3, 1999.

De Deckker, P., Magee, J. W., and Shelley, J. M. G.: Late Quaternary palaeohydrological changes in the large playa Lake Frome in central Australia, recorded from the $\mathrm{Mg} / \mathrm{Ca}$ and $\mathrm{Sr} / \mathrm{Ca}$ in ostracod valves and biotic remains, J. Arid Environ., 75, 38-50, https://doi.org/10.1016/j.jaridenv.2010.08.004, 2011.

Dee, S. G., Steiger, N. J., Emile-Geay, J., and Hakim, G. J.: On the utility of proxy system models for estimating climate states over the common era, J. Adv. Model. Earth Sy., 8, 1164-1179, https://doi.org/10.1002/2016ms000677, 2016.

Denniston, R. F., Wyrwoll, K.-H., Polyak, V. J., Brown, J. R., Asmerom, Y., Wanamaker Jr, A. D., LaPointe, Z., Ellerbroek, R., Barthelmes, M., Cleary, D., Cugley, J., Woods, D., and Humphreys, W. F.: A Stalagmite record of Holocene Indonesian-Australian summer monsoon variability from the Australian tropics, Quaternary Sci. Rev., 78, 155-168, https://doi.org/10.1016/j.quascirev.2013.08.004, 2013a.

Denniston, R. F., Wyrwoll, K.-H., Polyak, V. J., Brown, J. R., Asmerom, Y., Wanamaker Jr., A. D., LaPointe, Z., Ellerbroek, R., Barthelmes, M., Cleary, D., Cugley, J., Woods, D., and Humphreys, W. F.: A Stalagmite record of Holocene Indonesian-Australian summer monsoon variability from the Australian tropics, Quat. Sci. Rev., 78, 155-168, https://doi.org/10.1016/j.quascirev.2013.08.004, 2013b.

Desmarchelier, J. M., Hellstrom, J. C., and McCulloch, M. T.: Rapid trace element analysis of speleothems by ELA-ICP-MS, Chem. Geol., 231, 102-117, https://doi.org/10.1016/j.chemgeo.2006.01.002, 2006.

Dieffenbacher-Krall, A. C., Vandergoesa, M. J., and Denton, G. H.: An inference model for mean summer air temperatures in the Southern Alps, New Zealand, using sub- 
fossil chironomids, Quaternary Sci. Rev., 26, 2487-2504, https://doi.org/10.1016/j.quascirev.2007.06.016, 2007.

Donders, T. H., Haberle, S. G., Hope, G., Wagner, F., and Visscher, H.: Pollen evidence for the transition of the eastern Australian climate system from the post-glacial to the present-day ENSO mode, Quaternary Sci. Rev., 26, 1621-1637, https://doi.org/10.1016/j.quascirev.2006.11.018, 2007.

Dreybrodt, W. and Scholz, D.: Climatic dependence of stable carbon and oxygen isotope signals recorded in speleothems: from soil water to speleothem calcite, Geochim. Cosmochim. Ac., 75, 734-752, https://doi.org/10.1016/j.gca.2010.11.002, 2011.

Eden, D. N. and Page, M. J.: Palaeoclimatic implications of a storm erosion record from late Holocene lake sediments, North Island, New Zealand, Palaeogeogr. Palaeocl., 139, 37-58, 1998.

Elderfield, H. and Ganssen, G.: Past temperature and delta $\mathrm{O}^{-18}$ of surface ocean waters inferred from foraminiferal $\mathrm{Mg} / \mathrm{Ca}$ ratios, Nature, 405, 442-445, https://doi.org/10.1038/35013033, 2000.

Emile-Geay, J. and Eshleman, J. A.: Toward a semantic web of paleoclimatology, Geochem. Geophy. Geosy., 14, 457-469, https://doi.org/10.1002/ggge.20067, 2013.

Evans, M. N., Tolwinski-Ward, S. E., Thompson, D. M., and Anchukaitis, K. J.: Applications of proxy system modeling in high resolution paleoclimatology, Quaternary Sci. Rev., 76, 16-28, https://doi.org/10.1016/j.quascirev.2013.05.024, 2013.

Fairchild, I. J. and McMillan, E. A.: Speleothems as indicators of wet and dry periods, Int. J. Speleol., 36, 69-74, 2007.

Fairchild, I. J. and Treble, P. C.: Trace elements in speleothems as recorders of environmental change, Quaternary Sci. Rev., 28, 449-468, https://doi.org/10.1016/j.quascirev.2008.11.007, 2009.

Fairchild, I. J., Borsato, A., Tooth, A. F., Frisia, S., Hawkesworth, C. J., Huang, Y., McDermott, F., and Spiro, B.: Controls on trace element $(\mathrm{Sr}-\mathrm{Mg})$ compositions of carbonate cave waters: implications for speleothem climatic records, Chem. Geol., 166, 255-269, https://doi.org/10.1016/S00092541(99)00216-8, 2000.

Fairchild, I. J., Baker, A., Borsato, A., Frisia, S., Hinton, R. W., McDermott, F., and Tooth, A. F.: Annual to sub-annual resolution of multiple trace-element trends in speleothems, J. Geol. Soc., $158,831-841,2001$

Fairchild, I. J., Smith, C. L., Baker, A., Fuller, L., Spotl, C., Mattey, D., and McDermott, F.: Modification and preservation of environmental signals in speleothems, Earth-Sci. Rev., 75, 105153, https://doi.org/10.1016/j.earscirev.2005.08.003, 2006.

Farquhar, G. D., Hubick, K. T., Condon, A. G., and Richards, R. A.: Carbon isotope fractionation and plant wateruse efficiency, in: Ecological Studies, edited by: Rundel, P. W., Ehleringer, J. R., and Nagy, K. A., Ecological Studies, Springer, New York, 2140, 1988.

Fischer, M. J. and Treble, P. C.: Calibrating climate-delta $\mathrm{O}^{-18}$ regression models for the interpretation of high-resolution speleothem delta $\mathrm{O}^{-18}$ time series, J. Geophys. Res.-Atmos., 113, D17103, https://doi.org/10.1029/2007jd009694, 2008.

Fitzsimmons, K., Gell, P., Bickford, S., Barrows, T., Mooney, S., Denham, T., and Contributors, O.: The OZPACS database: a resource for understanding recent impacts on Australian ecosystems, Quaternary Australasia, 24, 2-6, 2007.

Fitzsimmons, K. E., Cohen, T. J., Hesse, P. P., Jansen, J., Nanson, G. C., May, J. H., Barrows, T. T., Haberlah, D., Hilgers, A., Kelly, T., Larsen, J., Lomax, J., and Tre- ble, P.: Late Quaternary palaeoenvironmental change in the Australian drylands, Quaternary Sci. Rev., 74, 78-96, https://doi.org/10.1016/j.quascirev.2012.09.007, 2013.

Fletcher, M. S. and Thomas, I.: A quantitative Late Quaternary temperature reconstruction from western Tasmania, Australia, Quaternary Sci. Rev., 29, 2351-2361, https://doi.org/10.1016/j.quascirev.2010.06.012, 2010a.

Fletcher, M. S. and Thomas, I.: A Holocene record of sea level, vegetation, people and fire from western Tasmania, Australia, Holocene, 20, 351-361, https://doi.org/10.1177/0959683609351903, 2010 b.

Fletcher, M. S., Wolfe, B. B., Whitlock, C., Pompeani, D. P., Heijnis, H., Haberle, S. G., Gadd, P. S., and Bowman, D.: The legacy of mid-Holocene fire on a Tasmanian montane landscape, J. Biogeogr., 41, 476-488, https://doi.org/10.1111/jbi.12229, 2014.

Frappier, A. B., Sahagian, D., Carpenter, S. J., González, L. A., and Frappier, B. R.: Stalagmite stable isotope record of recent tropical cyclone events, Geology, 35, 111-114, https://doi.org/10.1130/g23145a.1, 2007.

Freeman, R., Goodwin, I. D., and Donovan, T.-M.: The MQDECCW-NSW Paleoclimate Database and its Application to Reconstructing Past Climate Modes and Variability in SouthEastern Australia, Macquarie University, Sydney, Australia, 2011.

Gallant, A. J. E. and Gergis, J.: An experimental streamflow reconstruction for the River Murray, Australia, 1783-1988, Water Resour. Res., 47, W00G04, https://doi.org/10.1029/2010wr009832, 2011.

Gallant, A. J. E., Phipps, S. J., Karoly, D. J., Mullan, A. B., and Lorrey, A. M.: Nonstationary Australasian teleconnections and implications for Paleoclimate reconstructions, J. Climate, 26, 88278849, https://doi.org/10.1175/JCLI-D-12-00338.1, 2013.

Gehrels, M. J., Lowe, D. J., Hazell, Z. J., and Newnham, R. M.: A continuous 5300 yr Holocene cryptotephrostratigraphic record from northern New Zealand and implications for tephrochronology and volcanic hazard assessment, Holocene, 16, 173-187, https://doi.org/10.1191/0959683606hl1918rp, 2006.

Gehrels, M. J., Newnham, R. M., Lowe, D. J., Wynne, S., Hazell, Z. J., and Caseldine, C.: Towards rapid assay of cryptotephra in peat cores: review and evaluation of various methods, Quatern. Int., 178, 68-84, https://doi.org/10.1016/j.quaint.2006.10.014, 2008.

Gell, P. A.: The development of a diatom database for inferring lake salinity, western Victoria, Australia: towards a quantitative approach for reconstructing past climates, Aust. J. Bot., 45, 389423, https://doi.org/10.1071/bt96036, 1997.

Gell, P., Tibby, J., Fluin, J., Leahy, P., Reid, M., Adamson, K., Bulpin, S., MacGregor, A., Wallbrink, P., Hancock, G., and Walsh, B.: Accessing limnological change and variability using fossil diatom assemblages, south-east Australia, River Res. Appl., 21, 257-269, https://doi.org/10.1002/rra.845, 2005.

Gell, P., Tibby, J., Little, F., Baldwin, D., and Hancock, G.: The impact of regulation and salinisation on floodplain lakes: the lower River Murray, Australia, Hydrobiologia, 591, 135-146, https://doi.org/10.1007/s10750-007-0806-3, 2007.

Gell, P., Fluin, J., Tibby, J., Hancock, G., Harrison, J., Zawadzki, A., Haynes, D., Khanum, S., Little, F., and Walsh, B.: Anthropogenic acceleration of sediment accretion in lowland floodplain wetlands, Murray-Darling Basin, Australia, Geomorphology, 
108, 122-126, https://doi.org/10.1016/j.geomorph.2007.12.020, 2009.

Gergis, J., Gallant, A. J. E., Braganza, K., Karoly, D. J., Allen, K., Cullen, L., D’Arrigo, R., Goodwin, I., Grierson, P., and McGregor, S.: On the long-term context of the 1997-2009 "Big Dry" in South-Eastern Australia: insights from a 206 year multi-proxy rainfall reconstruction, Clim. Change, 111, 923944, https://doi.org/10.1007/s10584-011-0263-x, 2012.

Gergis, J., Neukom, R., Gallant, A. J. E., and Karoly, D. J.: Australasian temperature reconstructions spanning the last millennium, J. Climate, 29, 5365-5392, https://doi.org/10.1175/JCLID-13-00781.1, 2016.

Geyh, M. A.: An overview of ${ }^{14} \mathrm{C}$ analysis in the study of groundwater, Radiocarbon, 42, 99-114, 2000.

Gharibreza, M., Raj, J. K., Yusoff, I., Othman, Z., Tahir, W. Z. W. M., and Ashraf, M. A.: Sedimentation rates in Bera Lake (Peninsular Malaysia) using ${ }^{210} \mathrm{~Pb}$ and ${ }^{137} \mathrm{Cs}$ radioisotopes, Geosci. J., 17, 211-220, https://doi.org/10.1007/s12303-013-0013-3, 2013.

Gingele, F., De Deckker, P., and Norman, M.: Late Pleistocene and Holocene climate of SE Australia reconstructed from dust and river loads deposited offshore the River Murray Mouth, Earth Planet. Sc. Lett., 255, 257-272, https://doi.org/10.1016/j.epsl.2006.12.019, 2007.

Gliganic, L. A., Cohen, T. J., May, J.-H., Jansen, J. D., Nanson, G. C., Dosseto, A., Larsen, J. R., and Aubert, M.: Late-Holocene climatic variability indicated by three natural archives in arid southern Australia, Holocene, 24, 104-117, https://doi.org/10.1177/0959683613515732, 2014.

Goede, A.: Continuous early last glacial paleoenvironmental records from a Tasmanian speleothem based on stable isotope and minor element variations, Quaternary Sci. Rev., 13, 283-291, https://doi.org/10.1016/0277-3791(94)90031-0, 1994.

Gomez, B., Carter, L., Orpin, A. R., Cobb, K. M., Page, M. J., Trustrum, N. A., and Palmer, A. S.: ENSO/SAM interactions during the middle and late Holocene, Holocene, 22, 23-30, https://doi.org/10.1177/0959683611405241, 2012.

Goodwin, I., Browning, S., Lorrey, A., Mayewski, P., Phipps, S., Bertler, N. N., Edwards, R., Cohen, T., Ommen, T., Curran, M., Barr, C., and Stager, J. C.: A reconstruction of extratropical Indo-Pacific sea-level pressure patterns during the Medieval Climate Anomaly, Clim. Dynam., 43, 1197-1219, https://doi.org/10.1007/s00382-013-1899-1, 2013.

Goodwin, I. D., Browning, S. A., and Anderson, A. J.: Climate windows for Polynesian voyaging to New Zealand and Easter Island, P. Natl. Acad. Sci. USA, 111, 14716-14721, https://doi.org/10.1073/pnas.1408918111, 2014.

Goring, S., Williams, J. W., Blois, J. L., Jackson, S. T., Paciorek, C. J., Booth, R. K., Marlon, J. R., Blaauw, M., and Christen, J. A.: Deposition times in the northeastern United States during the Holocene: establishing valid priors for Bayesian age models, Quaternary Sci. Rev., 48, 54-60, https://doi.org/10.1016/j.quascirev.2012.05.019, 2012.

Gouramanis, C.: High-resolution Holocene palaeoenvironmental and palaeoclimatic changes recorded in southern Australian lakes based on ostracods and their chemical composition, PhD, Research School of Earth Science, Australian National University, Australian National University, Canberra, Australia, 308 pp., 2009.
Gouramanis, C. and De Deckker, P.: Alkalinity control on the partition coefficients in lacustrine ostracodes from Australia, Geology, 38, 359-362, https://doi.org/10.1130/g30235.1, 2010.

Gouramanis, C., Wilkins, D., and De Deckker, P.: 6000 years of environmental changes recorded in Blue Lake, South Australia, based on ostracod ecology and valve chemistry, Paleogeogr. Paleoclimatol. Paleoecol., 297, 223-237, https://doi.org/10.1016/j.palaeo.2010.08.005, 2010a.

Gouramanis, C., Wilkins, D., and De Deckker, P.: Blue Lake, South Australia 6000 year ostracod geochemical data, available at: https://www.ncdc.noaa.gov/paleo/study/22411 (last access: 17 October 2017), 2010 b.

Gouramanis, C., Dodson, J., Wilkins, D., De Deckker, P., and Chase, B. M.: Holocene palaeoclimate and sea level fluctuation recorded from the coastal Barker Swamp, Rottnest Island, south-western Western Australia, Quaternary Sci. Rev., 54, 4057, https://doi.org/10.1016/j.quascirev.2012.05.007, 2012.

Gouramanis, C., De Deckker, P., Switzer, A. D., and Wilkins, D.: Cross-continent comparison of high-resolution Holocene climate records from southern Australia - deciphering the impacts of far-field teleconnections, Earth-Sci. Rev., 121, 55-72, https://doi.org/10.1016/j.earscirev.2013.02.006, 2013.

Grant, P. J.: Major periods of erosion and alluvial sedimentation in New Zealand during the Late Holocene, J. Roy. Soc. New Zeal., 15, 67-121, 1985.

Green, J. D. and Lowe, D. J.: Stratigraphy and development of c. 17000 year old Lake Maratoto, North Island, New Zealand, with some inferences about postglacial climatic change, New Zeal. J. Geol. Geop., 28, 675-699, 1985.

Griffiths, M. L., Drysdale, R. N., Gagan, M. K., Zhao, J. X., Ayliffe, L. K., Hellstrom, J. C., Hantoro, W. S., Frisia, S., Feng, Y. X., Cartwright, I., Pierre, E. S., Fischer, M. J., and Suwargadi, B. W.: Increasing Australian-Indonesian monsoon rainfall linked to early Holocene sea-level rise, Nat. Geosci., 2, 636-639, https://doi.org/10.1038/ngeo605, 2009.

Griffiths, M. L., Drysdale, R. N., Gagan, M. K., Frisia, S., Zhao, J.X., Ayliffe, L. K., Hantoro, W. S., Hellstrom, J. C., Fischer, M. J., Feng, Y.-X., and Suwargadi, B. W.: Evidence for Holocene changes in Australian-Indonesian monsoon rainfall from stalagmite trace element and stable isotope ratios, Earth Planet. Sc. Lett., 292, 27-38, 2010.

Griffiths, M. L., Drysdale, R. N., Gagan, M. K., Zhao, J. X., Hellstrom, J. C., Ayliffe, L. K., and Hantoro, W. S.: Abrupt increase in east Indonesian rainfall from flooding of the Sunda Shelf similar to 9500 years ago, Quaternary Sci. Rev., 74, 273-279, https://doi.org/10.1016/j.quascirev.2012.07.006, 2013.

Griffiths, M. L., Kimbrough, A. K., Gagan, M. K., Drysdale, R. N., Cole, J. E., Johnson, K. R., Zhao, J. X., Cook, B. I., Hellstrom, J. C., and Hantoro, W. S.: Western Pacific hydroclimate linked to global climate variability over the past two millennia, Nat. Commun., 7, 11719, https://doi.org/10.1038/ncomms11719, $2016 a$.

Griffiths, M. L., Kimbrough, A. K., Gagan, M. K., Drysdale, R. N., Cole, J. E., Johnson, K. R., Zhao, J. X., Cook, B. I., Hellstrom, J. C., and Hantoro, W. S.: Liang Luar Cave, Indonesia 2000 year speleothem isotope and geochemical data, available at: https://www.ncdc.noaa.gov/paleo/study/20285 (last access: 17 October 2017), 2016 b. 
Haberle, S. G.: A 23000 yr pollen record from Lake Euramoo, Wet Tropics of NE Queensland, Australia, Quaternary Res., 64, 343356, https://doi.org/10.1016/j.yqres.2005.08.013, 2005.

Haberle, S. G., Tibby, J., Dimitriadis, S., and Heijnis, H.: The impact of European occupation on terrestrial and aquatic ecosystem dynamics in an Australian tropical rain forest, J. Ecol., 94, 9871002, https://doi.org/10.1111/j.1365-2745.2006.01140.x, 2006.

Haig, J., Nott, J., and Reichart, G.-J.: Australian tropical cyclone activity lower than at any time over the past 550-1 500 years, Nature, 505, 667-671, https://doi.org/10.1038/nature12882, available at: http://www.nature.com/nature/journal/v505/n7485/abs/ nature12882.html\#supplementary-information, 2014.

Hall, A. and Visbeck, M.: Synchronous variability in the Southern Hemisphere atmosphere, sea ice, and ocean resulting from the annular mode, J. Climate, 15, 3043-3057, https://doi.org/10.1175/15200442(2002)015<3043:svitsh>2.0.co;2, 2002.

Head, L., Adams, M., McGregor, H. V., and Toole, S.: Climate change and Australia, WIRES Clim. Change, 5, 175-197, https://doi.org/10.1002/wcc.255, 2014.

Herbert, A. V. and Harrison, S. P.: Evaluation of a modernanalogue methodology for reconstructing Australian palaeoclimate from pollen, Rev. Palaeobot. Palyno., 226, 65-77, https://doi.org/10.1016/j.revpalbo.2015.12.006, 2016.

Hesse, P. P.: The record of continental dust from Australia in Tasman Sea sediments, Quaternary Sci. Rev., 13, 257-272, https://doi.org/10.1016/0277-3791(94)90029-9, 1994.

Hesse, P. P. and McTainsh, G. H.: Australian dust deposits: modern processes and the Quaternary record, Quaternary Sci. Rev., 22, 2007-2035, https://doi.org/10.1016/s0277-3791(03)00164$1,2003$.

Heyng, A. M., Mayr, C., Lucke, A., Moschen, R., Wissel, H., Striewski, B., and Bauersachs, T.: Middle and Late Holocene paleotemperatures reconstructed from oxygen isotopes and GDGTs of sediments from Lake Pupuke, New Zealand, Quatern. Int., 374, 3-14, https://doi.org/10.1016/j.quaint.2014.12.040, 2015.

Ho, M., Verdon-Kidd, D. C., Kiem, A. S., and Drysdale, R. N.: Broadening the spatial applicability of Paleoclimate information - a case-study for the Murray-Darling Basin, Australia, J. Climate, 27, 2477-2495, https://doi.org/10.1175/jcli-d-13-00071.1, 2013.

Hogg, A. G., Hua, Q., Blackwell, P. G., Niu, M., Buck, C. E., Guilderson, T. P., Heaton, T. J., Palmer, J. G., Reimer, P. J., Reimer, R. W., Turney, C. S. M., and Zimmerman, S. R. H.: SHCAL13 Southern Hemisphere calibration, 0-50 000 years cal BP, Radiocarbon, 55, 1889-1903, 2013.

Hollins, S. E., Harrison, J. J., Jones, B. G., Zawadzki, A., Heijnis, H., and Hankin, S.: Reconstructing recent sedimentation in two urbanised coastal lagoons (NSW, Australia) using radioisotopes and geochemistry, J. Paleolimn., 46, 579-596, https://doi.org/10.1007/s10933-011-9555-4, 2011.

Hope, P., Henley, B. J., Gergis, J., Brown, J., and Ye, H.: Timevarying spectral characteristics of ENSO over the Last Millennium, Clim. Dynam., 49, 1705-1727, 2016.

Horrocks, M., Deng, Y., Ogden, J., Alloway, B. V., Nichol, S. L., and Sutton, D. G.: High spatial resolution of pollen and charcoal in relation to the c600 year BP Kaharoa Tephra: implications for Polynesian settlement of Great Barrier Is- land, Northern New Zealand, J. Archaeol. Sci., 28, 153-168, https://doi.org/10.1006/jasc.2000.0568, 2001.

Horrocks, M., Nichol, S. L., Augustinus, P. C., and Barber, I. G.: Late Quaternary environments, vegetation and agriculture in northern New Zealand, J. Quaternary Sci., 22, 267-279, https://doi.org/10.1002/jqs.1027, 2007.

Hua, Q., McDonald, J., Redwood, D., Drysdale, R., Lee, S., Fallon, S., and Hellstrom, J.: Robust chronological reconstruction for young speleothems using radiocarbon, Quat. Geochronol., 14, 67-80, https://doi.org/10.1016/j.quageo.2012.04.017, 2012.

Huang, S., Pollack, H. N., and Shen, P.-Y.: Temperature trends over the past five centuries reconstructed from borehole temperatures, Nature, 403, 756-758, 2000.

Jiang, N. B., Griffiths, G., and Lorrey, A.: Influence of large-scale climate modes on daily synoptic weather types over New Zealand, Int. J. Climatol., 33, 499-519, https://doi.org/10.1002/joc.3443, 2013.

Jones, D. A., Wang, W., and Fawcett, R.: High-quality spatial climate data-sets for Australia, Aust. Meteorol. Ocean., 58, 233248, 2009.

Jones, P. D., Briffa, K. R., Barnett, T. P., and Tett, S. F. B.: High-resolution palaeoclimatic records for the last millennium: interpretation, integration and comparison with general circulation model control-run temperatures, Holocene, 8, 455-471, https://doi.org/10.1191/095968398667194956, 1998.

Jones, R. N., McMahon, T., and Bowler, J. M.: Modelling historical lake levels and recent climate change at three closed lakes, Western Victoria, Australia (c. 1840-1990), J. Hydrol., 246, 159-180, https://doi.org/10.1016/s0022-1694(01)00369-9, 2001.

Kaufman, D.: A community-driven framework for climate reconstructions, Eos, Transactions American Geophysical Union, 95, 361-362, https://doi.org/10.1002/2014EO400001, 2014.

Kemp, J., Radke, L. C., Olley, J., Juggins, S., and De Deckker, P.: Holocene lake salinity changes in the Wimmera, southeastern Australia, provide evidence for millennialscale climate variability, Quaternary Res., 77, 65-76, https://doi.org/10.1016/j.yqres.2011.09.013, 2012a.

Kemp, J., Radke, L. C., Olley, J., Juggins, S., and De Deckker, P.: Wimmera Lakes, Australia Holocene ostracod salinity reconstruction, available at: https://www.ncdc.noaa.gov/paleo/study/ 22414 (last access: 17 October 2017), 2012b.

Kershaw, A. P.: A pollen diagram from Lake Euramoo, Northeast Queensland, Australia, New Phytol., 69, 785-805, https://doi.org/10.1111/j.1469-8137.1970.tb02463.x, 1970.

Kershaw, A. P.: Pollen diagram from Quincan Crater, Northeast Queensland, Australia, New Phytol., 70, 669-681, https://doi.org/10.1111/j.1469-8137.1971.tb02567.x, 1971.

Kershaw, A. P.: Stratigraphy and pollen analysis of Bromfield Swamp, Northeastern Queensland, Australia, New Phytol., 75, 173-191, https://doi.org/10.1111/j.1469-8137.1975.tb01385.x, 1975.

Kershaw, A. P.: A Holocene pollen diagram from Lynch's Crater, Northeastern Queensland, Australia, New Phytol., 94, 669-682, https://doi.org/10.1111/j.1469-8137.1983.tb04875.x, 1983.

Kershaw, A. P.: Pleistocene vegetation of the humid tropics of Northeastern Queensland, Australia, Paleogeogr. Paleoclimatol. Paleoecol., 109, 399-412, https://doi.org/10.1016/00310182(94)90188-0, 1994. 
Kershaw, A. P., D’Costa, D. M., Mason, J., and Wagstaff, B. E.: Palynological evidence for Quaternary vegetation and environments of mainland southeastern Australia, Quaternary Sci. Rev., 10, 391-404, https://doi.org/10.1016/0277-3791(91)90003-d, 1991.

Kershaw, A. P., Bretherton, S. C., and van der Kaars, S.: A complete pollen record of the last $230 \mathrm{ka}$ from Lynch's Crater, northeastem Australia, Paleogeogr. Paleoclimatol. Paleoecol., 251, 23-45, https://doi.org/10.1016/j.palaeo.2007.02.015, 2007.

Khider, D., Stott, L. D., Emile-Geay, J., Thunell, R., and Hammond, D. E.: Assessing El Nino Southern oscillation variability during the past millennium, Paleoceanography, 26, 20, https://doi.org/10.1029/2011pa002139, 2011.

Khider, D., Jackson, C. S., and Stott, L. D.: Assessingmillennialscale variability during the Holocene: a perspective from the western tropical Pacific, Paleoceanography, 29, 143-159, https://doi.org/10.1002/2013pa002534, 2014.

Kidson, J. W.: An analysis of New Zealand synoptic types and their use in defining weather regimes, Int. J. Climatol., 20, 299-316, https://doi.org/10.1002/(sici)10970088(20000315)20:3<299::aid-joc474>3.0.co;2-b, 2000.

Kiem, A. S., Johnson, F., Westra, S., van Dijk, A., Evans, J. P., O'Donnell, A., Rouillard, A., Barr, C., Tyler, J., Thyer, M., Jakob, D., Woldemeskel, F., Sivakumar, B., and Mehrotra, R.: Natural hazards in Australia: droughts, Clim. Change, 139, 3754, https://doi.org/10.1007/s10584-016-1798-7, 2016.

Konecky, B. L., Russell, J. M., Rodysill, J. R., Vuille, M., Bijaksana, S., and Huang, Y. S.: Intensification of southwestern Indonesian rainfall over the past millennium, Geophys. Res. Lett., 40, 386-391, https://doi.org/10.1029/2012gl054331, 2013a.

Konecky, B. L., Russell, J. M., Rodysill, J. R., Vuille, M., Bijaksana, S., and Huang, Y. S.: Intensification of southwestern Indonesian rainfall over the past millennium, Geophys. Res. Lett., 40, 386391, https://doi.org/10.1029/2012g1054331, 2013b.

Lachniet, M. S.: Climatic and environmental controls on speleothem oxygen-isotope values, Quaternary Sci. Rev., 28, 412-432, https://doi.org/10.1016/j.quascirev.2008.10.021, 2009.

Langton, S. J., Linsley, B. K., Robinson, R. S., Rosenthal, Y., Oppo, D. W., Eglinton, T. I., Howe, S. S., Djajadihardja, Y. S., and Syamsudin, F.: $3500 \mathrm{yr}$ record of centennial-scale climate variability from the Western Pacific Warm Pool, Geology, 36, 795-798, https://doi.org/10.1130/g24926a.1, 2008a.

Langton, S. J., Linsley, B. K., Robinson, R. S., Rosenthal, Y., Oppo, D. W., Eglinton, T. I., Howe, S. S., Djajadihardja, Y. S., and Syamsudin, F.: Langton et al., 2008 Kau Bay, Indonesia 3500year d15N ENSO record, available at: https://www.ncdc.noaa. gov/paleo/study/8676 (last access: 17 October 2017), 2008b.

Larocque-Tobler, I., Grosjean, M., and Kamenik, C.: Calibration-intime vs. calibration-in-space (transfer function) to quantitatively infer July air temperature using biological indicators (chironomids) preserved in lake sediments, Palaeogeogr. Palaeocl., 299, 281-288, https://doi.org/10.1016/j.palaeo.2010.11.008, 2011.

Lea, D. W., Mashiotta, T. A., and Spero, H. J.: Controls on magnesium and strontium uptake in planktonic foraminifera determined by live culturing, Geochim. Cosmochim. Ac., 63, 2369-2379, https://doi.org/10.1016/s0016-7037(99)00197-0, 1999.

Leahy, P. J., Tibby, J., Kershaw, A. P., Heijnis, H., and Kershaw, J. S.: The impact of European settlement on Bolin Bill- abong, a Yarra River floodplain lake, Melbourne, Australia, River Res. Appl., 21, 131-149, https://doi.org/10.1002/rra.837, 2005.

Lewis, S. C. and LeGrande, A. N.: Stability of ENSO and its tropical Pacific teleconnections over the Last Millennium, Clim. Past, 11, 1347-1360, https://doi.org/10.5194/cp-11-1347-2015, 2015.

Linsley, B. K., Rosenthal, Y., and Oppo, D. W.: Holocene evolution of the Indonesian throughflow and the western Pacific warm pool, Nat. Geosci., 3, 578-583, https://doi.org/10.1038/ngeo920, 2010.

Logan, B. and Taffs, K. H.: Relationship between diatoms and water quality (TN, TP) in sub-tropical east Australian estuaries, J. Paleolimnol., 50, 123-137, https://doi.org/10.1007/s10933-0139708-8, 2013.

Lorrey, A., Fowler, A. M., and Salinger, J.: Regional climate regime classification as a qualitative tool for interpreting multiproxy palaeoclimate data spatial patterns: a New Zealand case study, Paleogeogr. Paleoclimatol. Paleoecol., 253, 407-433, https://doi.org/10.1016/j.palaeo.2007.06.011, 2007.

Lorrey, A., Williams, P., Salinger, J., Martin, T., Palmer, J., Fowler, A., Zhao, J. X., and Neil, H.: Speleothem stable isotope records interpreted within a multi-proxy framework and implications for New Zealand palaeoclimate reconstruction, Quatern. Int., 187, 52-75, https://doi.org/10.1016/j.quaint.2007.09.039, 2008.

Lorrey, A., Fauchereau, N., Stanton, C., Chappell, P., Phipps, S., Mackintosh, A., Renwick, J., Goodwin, I., and Fowler, A.: The Little Ice Age climate of New Zealand reconstructed from Southern Alps cirque glaciers: a synoptic type approach, Clim. Dynam., 42, 3039-3060, https://doi.org/10.1007/s00382-013-1876$8,2014$.

Lorrey, A. M. and Bostock, H.: The climate of New Zealand through the Quaternary, in: Landscape and Quaternary Environmental Change in New Zealand, edited by: Shulmeister, J., Atlantis Press, Paris, 67-139, 2017.

Lorrey, A. M., Vandergoes, M., Renwick, J., Newnham, R., Ackerley, D., Bostock, H., Williams, P. W., King, D. N. T., Neil, H., Harper, S., Mackintosh, A., Goff, J., McFadgen, B., Martin, T., and Chappell, P.: A regional climate regime classification synthesis for New Zealand covering three critical periods of the late Quaternary: The last 2000 years, the mid-Holocene, and the end of the Last Glacial Coldest Period, University of Auckland, Auckland, 2010.

Lorrey, A. M., Vandergoes, M., Almond, P., Renwick, J., Stephens, T., Bostock, H., Mackintosh, A., Newnham, R., Williams, P. W., Ackerley, D., Neil, H., and Fowler, A. M.: Palaeocirculation across New Zealand during the last glacial maximum at similar to $21 \mathrm{ka}$, Quaternary Sci. Rev., 36, 189-213, https://doi.org/10.1016/j.quascirev.2011.09.025, 2012.

Lowe, D. J., Blaauw, M., Hogg, A. G., and Newnham, R. M.: Ages of 24 widespread tephras erupted since 30,000 years ago in New Zealand, with re-evaluation of the timing and palaeoclimatic implications of the Lateglacial cool episode recorded at Kaipo bog, Quaternary Sci. Rev., 74, 170-194, https://doi.org/10.1016/j.quascirev.2012.11.022, 2013.

Lynch, A. H., Beringer, J., Kershaw, P., Marshall, A., Mooney, S., Tapper, N., Turney, C., and Van Der Kaars, S.: Using the paleorecord to evaluate climate and fire interactions in Australia, Annu. Rev. Earth Pl. Sc., 35, 215-239, https://doi.org/10.1146/annurev.earth.35.092006.145055, 2007. 
Mann, M. E.: Climate over the past two millennia, in: Annual Review of Earth and Planetary Sciences, Annual Review of Earth and Planetary Sciences, 35, Annual Reviews, Palo Alto, 111136, 2007.

Mann, M. E. and Jones, P. D.: Global surface temperatures over the past two millennia, Geophys. Res. Lett., 30, 1820, https://doi.org/10.1029/2003g1017814, 2003.

Marcott, S. A., Shakun, J. D., Clark, P. U., and Mix, A. C.: A reconstruction of regional and global temperature for the past 11300 years, Science, 339, 1198-1201, https://doi.org/10.1126/science.1228026, 2013.

Markowska, M., Baker, A., Andersen, M. S., Jex, C. N., Cuthbert, M. O., Rau, G. C., Graham, P. W., Rutlidge, H., Mariethoz, G., Marjo, C. E., Treble, P. C., and Edwards, N.: Semiarid zone caves: evaporation and hydrological controls on $\delta^{18} \mathrm{O}$ drip water composition and implications for speleothem paleoclimate reconstructions, Quaternary Sci. Rev., 131, 285-301, https://doi.org/10.1016/j.quascirev.2015.10.024, 2016.

Martin, L., Mooney, S., and Goff, J.: Coastal wetlands reveal a non-synchronous island response to sea-level change and a palaeostorm record from $5.5 \mathrm{kyr}$ to present, Holocene, 24, 569580, https://doi.org/10.1177/0959683614522306, 2014.

Marx, S. K. and Kamber, B. S.: Trace-element systematics of sediments in the Murray-Darling Basin, Australia: sediment provenance and palaeoclimate implications of fine scale chemical heterogeneity, Appl. Geochem., 25, 1221-1237, https://doi.org/10.1016/j.apgeochem.2010.05.007, 2010.

Marx, S. K., Kamber, B. S., and McGowan, H. A.: Provenance of long-travelled dust determined with ultra-traceelement composition: a pilot study with samples from New Zealand glaciers, Earth Surf. Proc. Land., 30, 699-716, https://doi.org/10.1002/esp.1169, 2005.

Marx, S. K., McGowan, H. A., and Kamber, B. A.: Upper Ruined Hut Bog, New Zeland 7700 year dust deposition data, available at: https://www.ncdc.noaa.gov/paleo/study/22410 (last access: 17 October 2017), 2009a.

Marx, S. K., McGowan, H. A., and Kamber, B. S.: Long-range dust transport from eastern Australia: A proxy for Holocene aridity and ENSO-type climate variability, Earth Planet. Sci. Lett., 282, 167-177, https://doi.org/10.1016/j.epsl.2009.03.013, 2009b.

Marx, S. K., Kamber, B. A., McGowan, H. A., and Denholm, J.: Upper Snowy Mountains, Australia 6500 year dust deposition data, available at: https://www.ncdc.noaa.gov/paleo/study/22413 (last access: 17 October 2017), 2011a.

Marx, S. K., Kamber, B. S., McGowan, H. A., and Denholm, J.: Holocene dust deposition rates in Australia's Murray-Darling Basin record the interplay between aridity and the position of the mid-latitude westerlies, Quat. Sci. Rev., 30, 3290-3305, https://doi.org/10.1016/j.quascirev.2011.07.015, $2011 \mathrm{~b}$.

Masson-Delmotte, V., Schulz, M., Abe-Ouchi, A., Beer, J., Ganopolski, A., González-Rouco, J. F., Jansen, E., Lambeck, K., Luterbacher, J., Naish, T., Osborn, T., Otto-Bliesner, B., Quinn, T., Ramesh, R., Rojas, M., Shao, X., and Timmermann, A.: Information from Paleoclimate Archives, Cambridge University Press, Cambridge, UK, New York, NY, USA, 2013.

McDonald, J., Drysdale, R., and Hill, D.: The 2002-2003 El Nino recorded in Australian cave drip waters: implications for reconstructing rainfall histories using stalagmites, Geophys. Res. Lett., 31, L22202, https://doi.org/10.1029/2004GL020859, 2004.
McFadgen, B.: Hostile Shores: Catastrophic Events in Prehistoric New Zealand and their Impact on Maori Coastal Communities, Auckland University Press, Auckland, 2007.

McFadgen, B. G.: Dating New Zealand archaeology by radiocarbon, New Zeal. J. Sci., 25, 379-392, 1982.

McGlone, M. S.: The late quaternary peat, vegetation and climate history of the southern oceanic islands of New Zealand, Quaternary Sci. Rev., 21, 683-707, https://doi.org/10.1016/s02773791(01)00044-0, 2002a.

McGlone, M. S.: A Holocene and latest Pleistocene pollen record from Lake Poukawa, Hawke's Bay, New Zealand, Global Planet. Change, 33, 283-299, https://doi.org/10.1016/s09218181(02)00083-8, 2002b.

McGlone, M. S. and Wilmshurst, J. M.: A Holocene record of climate, vegetation change and peat bog development, east Otago, South Island, New Zealand, J. Quaternary Sci., 14, 239-254, https://doi.org/10.1002/(sici)1099-1417(199905)14:3<239::aidjqs438>3.0.co;2-9, 1999a.

McGlone, M. S. and Wilmshurst, J. M.: Dating initial Maori environmental impact in New Zealand, Quatern. Int., 59, 5-16, https://doi.org/10.1016/S1040-6182(98)00067-6, 1999b.

McGlone, M. S., Turney, C. S. M., Wilmshurst, J. M., Renwick, J., and Pahnke, K.: Divergent trends in land and ocean temperature in the Southern Ocean over the past 18000 years, Nat. Geosci., 3, 622-626, https://doi.org/10.1038/ngeo931, 2010.

McGowan, H. A., Kamber, B., McTainsh, G. H., and Marx, S. K.: High resolution provenancing of long travelled dust deposited on the Southern Alps, New Zealand, Geomorphology, 69, 208-221, https://doi.org/10.1016/j.geomorph.2005.01.005, 2005.

McGowan, H. A., Petherick, L. M., and Kamber, B. S.: Aeolian sedimentation and climate variability during the late Quaternary in southeast Queensland, Australia, Palaeogeogr. Palaeocl., 265, 171-181, https://doi.org/10.1016/j.palaeo.2008.05.011, 2008.

McKay, N. P. and Emile-Geay, J.: Technical note: The Linked Paleo Data framework - a common tongue for paleoclimatology, Clim. Past, 12, 1093-1100, https://doi.org/10.5194/cp-12-10932016, 2016.

Meehl, G. A. and Arblaster, J. M.: The tropospheric biennial oscillation and Asian-Australian monsoon rainfall, J. Climate, 15, 722-744, https://doi.org/10.1175/15200442(2002)015<0722:ttboaa>2.0.co;2, 2002.

Moar, N. T.: Contributions to the quaternary history of the New Zealand flora, New Zeal. J. Bot., 5, 394-399, https://doi.org/10.1080/0028825X.1967.10428754, 1967.

Moberg, A., Sonechkin, D. M., Holmgren, K., Datsenko, N. M., and Karlen, W.: Highly variable Northern Hemisphere temperatures reconstructed from low- and high-resolution proxy data, Nature, 433, 613-617, https://doi.org/10.1038/nature03265, 2005.

Mohtadi, M., Prange, M., Oppo, D. W., De Pol-Holz, R., Merkel, U., Zhang, X., Steinke, S., and Lückge, A.: North Atlantic forcing of tropical Indian Ocean climate, Nature, 509, 7680, https://doi.org/10.1038/nature13196, 2014.

Mooney, S.: A fine-resolution paleoclimatic reconstruction of the last 2000 years, from Lake Keilambete, southeastern Australia, Holocene, 7, 139-149, https://doi.org/10.1177/095968369700700202, 1997.

Mooney, S. D. and Dodson, J. R.: A comparison of the environmental changes of the post-European period with those of the preceding 2000 years at Lake Keilam- 
bete, south-western Victoria, Aust. Geogr., 32, 163-179, https://doi.org/10.1080/00049180120066634, 2001.

Mooney, S. D., Harrison, S. P., Bartlein, P. J., Daniau, A. L., Stevenson, J., Brownlie, K. C., Buckman, S., Cupper, M., Luly, J., Black, M., Colhoun, E., D'Costa, D., Dodson, J., Haberle, S., Hope, G. S., Kershaw, P., Kenyon, C., McKenzie, M., and Williams, N.: Late Quaternary fire regimes of Australasia, Quaternary Sci. Rev., 30, 28-46, https://doi.org/10.1016/j.quascirev.2010.10.010, 2011.

Murphy, B. F. and Timbal, B.: A review of recent climate variability and climate change in southeastern Australia, Int. J. Climatol., 28, 859-879, https://doi.org/10.1002/joc.1627, 2008.

Nagra, G., Treble, P. C., Andersen, M. S., Fairchild, I. J., Coleborn, K., and Baker, A.: A post-wildfire response in cave dripwater chemistry, Hydrol. Earth Syst. Sci., 20, 2745-2758, https://doi.org/10.5194/hess-20-2745-2016, 2016.

Neukom, R. and Gergis, J.: Southern Hemisphere high-resolution palaeoclimate records of the last 2000 years, Holocene, 22, 501524, https://doi.org/10.1177/0959683611427335, 2012.

Newton, A., Thunell, R., and Stott, L.: Climate and hydrographic variability in the Indo-Pacific Warm Pool during the last millennium, Geophys. Res. Lett., 33, L19710, https://doi.org/10.1029/2006gl027234, 2006a.

Newton, A., Thunell, R. C., and Stott, L. D.: Indo-Pacific Warm Pool (MD98-2160) last millennium $\mathrm{Mg} / \mathrm{Ca}, \mathrm{d} 18 \mathrm{O}, \mathrm{SST}$, salinity data, available at: https://www.ncdc.noaa.gov/paleo/study/5534 (last access: 17 October 2017), 2006b.

Newton, A., Thunell, R., and Stott, L.: Changes in the Indonesian throughflow during the past $2000 \mathrm{yr}$, Geology, 39, 63-66, https://doi.org/10.1130/g31421.1, 2011a.

Newton, A., Thunell, R. C., and Stott, L. D.: Makassar Strait 2000 year foraminiferal $\mathrm{Mg} / \mathrm{Ca}$ and stable isotope data, https://www. ncdc.noaa.gov/paleo/study/12906 (last access: 17 October 2017), 2011b.

NOAA: Originally published and bacon-derived recalibrated agedepth models, available at: ftp://ftp.ncdc.noaa.gov/pub/data/ paleo/pages2k/dixon2017australasia/, last access: 26 October 2017.

Oppo, D. W., Rosenthal, Y., and Linsley, B. K.: 2009 Makssar Strait 2000 year SST and d18Osw, availabale at: https://www. ncdc.noaa.gov/paleo/study/8699 (last access: 17 October 2017), 2009a.

Oppo, D. W., Rosenthal, Y., and Linsley, B. K.: 2000 yearlong temperature and hydrology reconstructions from the Indo-Pacific warm pool, Nature, 460, 1113-1116, https://doi.org/10.1038/nature08233, 2009b.

PAGES2k Consortium, Ahmed, M., Anchukaitis, K. J., Asrat, A., Borgaonkar, H. P., Braida, M., Buckley, B. M., Buntgen, U., Chase, B. M., Christie, D. A., Cook, E. R., Curran, M. A. J., Diaz, H. F., Esper, J., Fan, Z. X., Gaire, N. P., Ge, Q. S., Gergis, J., Gonzalez-Rouco, J. F., Goosse, H., Grab, S. W., Graham, N., Graham, R., Grosjean, M., Hanhijarvi, S. T., Kaufman, D. S., Kiefer, T., Kimura, K., Korhola, A. A., Krusic, P. J., Lara, A., Lezine, A. M., Ljungqvist, F. C., Lorrey, A. M., Luterbacher, J., Masson-Delmotte, V., McCarroll, D., McConnell, J. R., McKay, N. P., Morales, M. S., Moy, A. D., Mulvaney, R., Mundo, I. A., Nakatsuka, T., Nash, D. J., Neukom, R., Nicholson, S. E., Oerter, H., Palmer, J. G., Phipps, S. J., Prieto, M. R., Rivera, A., Sano, M., Severi, M., Shanahan, T. M.,
Shao, X. M., Shi, F., Sigl, M., Smerdon, J. E., Solomina, O. N., Steig, E. J., Stenni, B., Thamban, M., Trouet, V., Turney, C. S. M., Umer, M., van Ommen, T., Verschuren, D., Viau, A. E., Villalba, R., Vinther, B. M., von Gunten, L., Wagner, S., Wahl, E. R., Wanner, H., Werner, J. P., White, J. W. C., Yasue, K., and Zorita, E.: Continental-scale temperature variability during the past two millennia, Nat. Geosci., 6, 339-346, https://doi.org/10.1038/ngeo1797, 2013.

Partin, J. W., Cobb, K. M., Adkins, J. F., Clark, B., and Fernandez, D. P.: Millennial-scale trends in west Pacific warm pool hydrology since the Last Glacial Maximum, Nature, 449, 452-455, https://doi.org/10.1038/nature06164, 2007.

Partin, J. W., Quinn, T. M., Shen, C.-C., Emile-Geay, J., Taylor, F. W., Maupin, C. R., Lin, K., Jackson, C. S., Banner, J. L., Sinclair, D. J., and Huh, C.-A.: Multidecadal rainfall variability in South Pacific convergence zone as revealed by stalagmite geochemistry, Geology, 41, 1143-1146, https://doi.org/10.1130/g34718.1, 2013.

Petherick, L. M., McGowan, H. A., and Kamber, B. S.: Reconstructing transport pathways for late Quaternary dust from eastern Australia using the composition of trace elements of long traveled dusts, Geomorphology, 105, 67-79, https://doi.org/10.1016/j.geomorph.2007.12.015, 2009.

Phipps, S. J., McGregor, H. V., Gergis, J., Gallant, A. J. E., Neukom, R., Stevenson, S., Ackerley, D., Brown, J. R., Fischer, M. J., and van Ommen, T. D.: Paleoclimate data-model comparison and the role of climate forcings over the past 1500 years, J. Climate, 26, 6915-6936, https://doi.org/10.1175/jcli-d-12-00108.1, 2013.

Pollack, H. N., Huang, S. P., and Smerdon, J. E.: Five centuries of climate change in Australia: the view from underground, J. Quaternary Sci., 21, 701-706, https://doi.org/10.1002/jqs.1060, 2006.

Power, M. J., Marlon, J. R., Bartlein, P. J., and Harrison, S. P.: Fire history and the Global Charcoal Database: a new tool for hypothesis testing and data exploration, Palaeogeogr. Palaeocl., 291, 52-59, https://doi.org/10.1016/j.palaeo.2009.09.014, 2010.

Prahl, F. G. and Wakeham, S. G.: Calibration of unsaturated patterns in long-chain ketone compositions for paleotemperature assessment, Nature, 330, 367-369, https://doi.org/10.1038/330367a0, 1987.

Quigley, M. C., Horton, T., Hellstrom, J. C., Cupper, M. L., and Sandiford, M.: Holocene climate change in arid Australia from speleothem and alluvial records, Holocene, 20, 1093-1104, https://doi.org/10.1177/0959683610369508, 2010.

R Core Team: R: A language and environment for statistical computing, R Foundation for Statistical Computing, Vienna, Australia, 2015.

Rees, A. B. H. and Cwynar, L. C.: Evidence for early postglacial warming in Mount Field National Park, Tasmania, Quaternary Sci. Rev., 29, 443-454, https://doi.org/10.1016/j.quascirev.2009.10.003, 2010.

Rees, A. B. H., Cwynar, L. C., and Cranston, P. S.: Midges (Chironomidae, Ceratopogonidae, Chaoboridae) as a temperature proxy: a training set from Tasmania, Australia, J. Paleolimnol., 40, 1159-1178, https://doi.org/10.1007/s10933-008-92226, 2008.

Reeves, J. M., Barrows, T. T., Cohen, T. J., Kiem, A. S., Bostock, H. C., Fitzsimmons, K. E., Jansen, J. D., Kemp, J., 
Krause, C., Petherick, L., Phipps, S. J., and Members, O.I.: Climate variability over the last 35,000 years recorded in marine and terrestrial archives in the Australian region: an OZ-INTIMATE compilation, Quaternary Sci. Rev., 74, 21-34, https://doi.org/10.1016/j.quascirev.2013.01.001, 2013a.

Reeves, J. M., Bostock, H. C., Ayliffe, L. K., Barrows, T. T., De Deckker, P., Devriendt, L. S., Dunbar, G. B., Drysdale, R. N., Fitzsimmons, K. E., Gagan, M. K., Griffiths, M. L., Haberle, S. G., Jansen, J. D., Krause, C., Lewis, S., McGregor, H. V., Mooney, S. D., Moss, P., Nanson, G. C., Purcell, A., and van der Kaars, S.: Palaeoenvironmental change in tropical Australasia over the last 30000 years - a synthesis by the OZ-INTIMATE group, Quaternary Sci. Rev., 74, 97-114, https://doi.org/10.1016/j.quascirev.2012.11.027, 2013 b.

Reimer, P. J., Bard, E., Bayliss, A., Beck, J. W., Blackwell, P. G., Ramsey, C. B., Buck, C. E., Cheng, H., Edwards, R. L., Friedrich, M., Grootes, P. M., Guilderson, T. P., Haflidason, H., Hajdas, I., Hatte, C., Heaton, T. J., Hoffmann, D. L., Hogg, A. G., Hughen, K. A., Kaiser, K. F., Kromer, B., Manning, S. W., Niu, M., Reimer, R. W., Richards, D. A., Scott, E. M., Southon, J. R., Staff, R. A., Turney, C. S. M., and van der Plicht, J.: INTCAL13 AND MARINE13 radiocarbon age calibration curves 0-50000 years cal BP, Radiocarbon, 55, 18691887, 2013.

Rodgers, K. B., Mikaloff-Fletcher, S. E., Bianchi, D., Beaulieu, C., Galbraith, E. D., Gnanadesikan, A., Hogg, A. G., Iudicone, D., Lintner, B. R., and Naegler, T.: Interhemispheric gradient of atmospheric radiocarbon reveals natural variability of Southern Ocean winds, Clim. Past., 7, 1123-1138, 2011.

Rodysill, J. R., Russell, J. M., Bijaksana, S., Brown, E. T., Safiuddin, L. O., and Eggermont, H.: A paleolimnological record of rainfall and drought from East Java, Indonesia during the last 1400 years, J. Paleolimnol., 47, 125-139, https://doi.org/10.1007/s10933-011-9564-3, 2012a.

Rodysill, J. R., Russell, J. M., Bijaksana, S., Brown, E. T., Safiuddin, L. O., and Eggermont, H.: Lake Logung, Indonesia 1400 year multiproxy sediment data, available at: https://www. ncdc.noaa.gov/paleo/study/13177 (last access: 17 October 2017), 2012b.

Rodysill, J. R., Russell, J. M., Crausbay, S. D., Bijaksana, S., Vuille, M., Edwards, R. L., and Cheng, H.: A severe drought during the last millennium in East Java, Indonesia, Quaternary Sci. Rev., 80, 102-111, https://doi.org/10.1016/j.quascirev.2013.09.005, 2013.

Roop, H. A., Dunbar, G. B., Levy, R., Vandergoes, M. J., Forrest, A. L., Walker, S. L., Purdie, J., Upton, P., and Whinney, J.: Seasonal controls on sediment transport and deposition in Lake Ohau, South Island, New Zealand: implications for a highresolution Holocene palaeoclimate reconstruction, Sedimentology, 62, 826-844, https://doi.org/10.1111/sed.12162, 2015.

Roop, H. A., Levy, R., Dunbar, G. B., Vandergoes, M. J., Howarth, J., Fitzsimons, S., Moon, H., Zammit, C., Ditchburn, R., Baisden, T., and Yoon, H. I.: A hydroclimate-proxy model based on sedimentary facies in an annually laminated sequence from Lake Ohau, South Island, New Zealand, J. Paleolimnol., 55, 1-16, https://doi.org/10.1007/s10933-015-9853-3, 2016.

Sachse, D., Radke, J., and Gleixner, G.: $\delta \mathrm{D}$ values of individual $\mathrm{n}$-alkanes from terrestrial plants along a climatic gradient - im- plications for the sedimentary biomarker record, Org. Geochem., 37, 469-483, https://doi.org/10.1016/j.orggeochem.2005.12.003, 2006.

Saunders, K. M.: A diatom dataset and diatom-salinity inference model for southeast Australian estuaries and coastal lakes, J. Paleolimnol., 46, 525-542, https://doi.org/10.1007/s10933-0109456-y, 2011.

Saunders, K. M., McMinn, A., Roberts, D., Hodgson, D. A., and Heijnis, H.: Recent human-induced salinity changes in Ramsarlisted Orielton Lagoon, south-east Tasmania, Australia: a new approach for coastal lagoon conservation and management, Aquat Conserv., 17, 51-70, https://doi.org/10.1002/aqc.732, 2007.

Saunders, K. M., Hodgson, D. A., Harrison, J., and McMinn, A.: Palaeoecological tools for improving the management of coastal ecosystems: a case study from Lake King (Gippsland Lakes) Australia, J. Paleolimnol., 40, 33-47, https://doi.org/10.1007/s10933-007-9132-z, 2008.

Saunders, K. M., Kamenik, C., Hodgson, D. A., Hunziker, S., Siffert, L., Fischer, D., Fujak, M., Gibson, J. A. E., and Grosjean, M.: Late Holocene changes in precipitation in northwest Tasmania and their potential links to shifts in the Southern Hemisphere westerly winds, Global Planet. Change, 92, 82-91, https://doi.org/10.1016/j.gloplacha.2012.04.005, 2012a.

Saunders, K. M., Kamenik, C., Hodgson, D. A., Hunziker, S., Siffert, L., Fischer, D., Fujak, M., Gibson, J. A. E., and Grosjean, M.: Rebecca Lagoon, Tasmania 3700 year sediment reflectance and precipitation reconstruction, available at: https: //www.ncdc.noaa.gov/paleo/study/22416 (last access: 17 October 2017), 2012b.

Saunders, K. M., Grosjean, M., and Hodgson, D. A.: A $950 \mathrm{yr}$ temperature reconstruction from Duckhole Lake, Southern Tasmania, Australia, Holocene, 23, 771-783, https://doi.org/10.1177/0959683612470176, 2013a.

Saunders, K. M., Grosjean, M., and Hodgson, D. A.: Duckhole Lake, Tasmania 950 year sediment reflectance and temperature reconstruction, available at: https://www.ncdc.noaa.gov/paleo/ study/20452 (last access: 17 October 2017), 2013b.

Schaefer, J. M., Denton, G. H., Kaplan, M. R., Putnam, A., Finkel, R. C., Barrell, D. J. A., Andersen, B. G., Schwartz, R., Mackintosh, A., Chinn, T., and Schluchter, C.: Highfrequency Holocene glacier fluctuations in New Zealand differ from the northern signature, Science, 324, 622-625, https://doi.org/10.1126/science.1169312, 2009.

Scholz, D., Hoffmann, D. L., Hellstrom, J., and Bronk Ramsey, C.: A comparison of different methods for speleothem age modelling, Quat. Geochronol., 14, 94-104, 2012.

Sikes, E. L., Medeiros, P. M., Augustinus, P., Wilmshurst, J. M., and Freeman, K. R.: Seasonal variations in aridity and temperature characterize changing climate during the last deglaciation in New Zealand, Quaternary Sci. Rev., 74, 245-256, https://doi.org/10.1016/j.quascirev.2013.01.031, 2013.

Sloss, C. R., Jones, B. G., Brooke, B. P., Heijnis, H., and Murray-Wallace, C. V.: Contrasting sedimentation rates in Lake Illawarra and St George Basin, two large barrier estuaries on the southeast coast of Australia, J. Paleolimnol., 46, 561-577, https://doi.org/10.1007/s10933-011-9507-z, 2011.

Smith, R. E., Tyler, J. J., Reeves, J., Blockley, S., and Jacobsen, G. E.: First Holocene cryptotephras in mainland Australia reported from sediments at Lake Keilam- 
bete, Victoria, Australia, Quat. Geochronol., 40, 82-91, https://doi.org/10.1016/j.quageo.2016.08.007, 2016.

Stanley, S. and De Deckker, P.: A Holocene record of allochthonous, aeolian mineral grains in an Australian alpine lake; implications for the history of climate change in southeastern Australia, J. Paleolimnol., 27, 207-219, https://doi.org/10.1023/a:1014249404845, 2002.

Steinke, S., Mohtadi, M., Groeneveld, J., Lin, L. C., Lowemark, L., Chen, M. T., and Rendle-Buhring, R.: Reconstructing the Southern South China Sea upper water column structure since the Last Glacial Maximum: implications for the East Asian winter monsoon development, Paleoceanography, 25, Pa2219, https://doi.org/10.1029/2009pa001850, 2010.

Steinke, S., Mohtadi, M., Prange, M., Varma, V., Pittauerova, D., and Fischer, H. W.: Mid- to Late-Holocene AustralianIndonesian summer monsoon variability, Quaternary Sci. Rev., 93, 142-154, https://doi.org/10.1016/j.quascirev.2014.04.006, 2014a.

Steinke, S., Mohtadi, M., Prange, M., Varma, V., Pittauerova, D., and Fischer, H. W.: Bulk sediment element analysis of sediment cores GeoB10065-9 and GeoB10065-7, offshore northwest Sumba Island, Indonesia, available at: https://doi.org/10.1594/PANGAEA.832475 (last access: 17 October 2017), 2014b.

Steinke, S., Mohtadi, M., Prange, M., Varma, V., Varma, V., Vugts, H. F., and Fischer, H. W.: Calcium (Ca), Titanium (Ti), and Iron (Fe) intensity XRF logs and lnratio between $\mathrm{Ti}$ and $\mathrm{Ca}$ of sediment core GeoB10065-7, https://doi.org/10.1594/PANGAEA.832385 (last access: 17 October 2017), 2014c.

Steinke, S., Prange, M., Feist, C., Groeneveld, J., and Mohtadi, M.: Upwelling variability off southern Indonesia over the past two millennia, Geophys. Res. Lett., 41, 7684-7693, https://doi.org/10.1002/2014GL061450, 2014d.

Steinke, S., Prange, M., Feist, C., Groeneveld, J., and Mohtadi, M.: Planktonic foraminifera $\mathrm{Mg} / \mathrm{Ca}$-based temperatures and planktonic foraminiferal cenus counts of core GeoB10065-7 (Lombok Basin, Indonesia), https://doi.org/10.1594/PANGAEA.837601 (last access: 17 October 2017), 2014e.

Stott, L., Cannariato, K., Thunell, R., Haug, G. H., Koutavas, A., and Lund, S.: Decline of surface temperature and salinity in the western tropical Pacific Ocean in the Holocene epoch, Nature, 431, 56-59, https://doi.org/10.1038/nature02903, 2004a.

Stott, L. D., Cannariato, K. G., Thunell, R. C., Haug, G. H., Koutavas, A., and Lund, S. P.: Western tropical Pacific Holocene sea surface temperature and salinity reconstructions, available at: https://www.ncdc.noaa.gov/paleo/study/2634 (last access: 17 October 2017), 2004b.

Stott, L., Timmermann, A., and Thunell, R.: Southern hemisphere and deep-sea warming led deglacial atmospheric $\mathrm{CO}(2)$ rise and tropical warming, Science, 318, 435-438, https://doi.org/10.1126/science.1143791, 2007a.

Stott, L. D., Timmermann, A., and Thunell, R. C.: Western tropical Pacific, $21 \mathrm{Kyr}$ BP to present, foraminiferal stable isotope, $\mathrm{Mg} / \mathrm{Ca}$, and SST data, available at: https://www.ncdc.noaa.gov/ paleo/study/6400 (last access: 17 October 2017), 2007b.

Suman, A., Dyer, F., and White, D.: Late Holocene temperature variability in Tasmania inferred from borehole tempera- ture data, Clim. Past, 13, 559-572, https://doi.org/10.5194/cp13-559-2017, 2017.

Taffs, K. H., Farago, L. J., Heijnis, H., and Jacobsen, G.: A diatombased Holocene record of human impact from a coastal environment: Tuckean Swamp, eastern Australia, J. Paleolimnol., 39, 71-82, https://doi.org/10.1007/s10933-007-9096-z, 2008.

Tait, A., Henderson, R., Turner, R., and Zheng, X.: Thin plate smoothing spline interpolation of daily rainfall for New Zealand using a climatological rainfall surface, Int. J. Climatol., 26, 2097-2115, https://doi.org/10.1002/joc.1350, 2006.

Telford, R. J., Heegaard, E., and Birks, H. J. B.: All age-depth models are wrong: but how badly?, Quaternary Sci. Rev., 23, 1-5, https://doi.org/10.1016/j.quascirev.2003.11.003, 2004.

Tibby, J.: Development of a diatom-based model for inferring total phosphorus in southeastern Australian water storages, J. Paleolimnol., 31, 23-36, https://doi.org/10.1023/B:JOPL.0000013272.25122.2a, 2004.

Tibby, J. and Taffs, K. H.: Palaeolimnology in eastern and southern Australian estuaries, J. Paleolimnol., 46, 503-510, https://doi.org/10.1007/s10933-011-9567-0, 2011.

Tibby, J., Reid, M. A., Fluin, J., Hart, B. T., and Kershaw, A. P.: Assessing long-term $\mathrm{pH}$ change in an Australian river catchment using monitoring and palaeolimnological data, Environ. Sci. Technol., 37, 3250-3255, https://doi.org/10.1021/es0263644, 2003.

Tibby, J., Gell, P., Hancock, G., and Clark, M.: Complex reservoir sedimentation revealed by an unusual combination of sediment records, Kangaroo Creek Reservoir, South Australia, J. Paleolimnol., 43, 535-549, https://doi.org/10.1007/s10933-0099349-0, 2010.

Tierney, J. E., Oppo, D. W., Rosenthal, Y., Russell, J. M., and Linsley, B.: Makassar Strait 2300 year leaf wax hydrogen isotope data, available at: https://www.ncdc.noaa.gov/paleo/study/10438 (last access: 17 October 2017), 2010a.

Tierney, J. E., Oppo, D. W., Rosenthal, Y., Russell, J. M., and Linsley, B. K.: Coordinated hydrological regimes in the IndoPacific region during the past two millennia, Paleoceanography, 25, PA1102, https://doi.org/10.1029/2009pa001871, 2010b.

Trachsel, M. and Telford, R. J.: All age-depth models are wrong, but are getting better, Holocene, 27, 860-869, https://doi.org/10.1177/0959683616675939, 2017.

Treble, P., Shelley, J. M. G., and Chappell, J.: Comparison of high resolution sub-annual records of trace elements in a modern (1911-1992) speleothem with instrumental climate data from southwest Australia, Earth Planet. Sc. Lett., 216, 141-153, https://doi.org/10.1016/s0012-821x(03)00504-1, 2003.

Treble, P. C., Chappell, J., Gagan, M. K., McKeegan, K. D., and Harrison, T. M.: In situ measurement of seasonal delta $\mathrm{O}^{-18}$ variations and analysis of isotopic trends in a modem speleothem from southwest Australia, Earth Planet. Sc. Lett., 233, 17-32, https://doi.org/10.1016/j.eps1.2005.02.013, 2005a.

Treble, P. C., Chappell, J., and Shelley, J. M. G.: Complex speleothem growth processes revealed by trace element mapping and scanning electron microscopy of annual layers, Geochim. Cosmochim. Ac., 69, 4855-4863, https://doi.org/10.1016/j.gca.2005.06.008, 2005b.

Treble, P. C., Bradley, C., Wood, A., Baker, A., Jex, C. N., Fairchild, I. J., Gagan, M. K., Cowley, J., and Azcurra, C.: An isotopic and modelling study of flow paths and storage in Quaternary calcarenite, SW Australia; implications for 
speleothem paleoclimate records, Quaternary Sci. Rev., 64, 90103, https://doi.org/10.1016/j.quascirev.2012.12.015, 2013.

Tyler, J. J., Mills, K., Barr, C., Sniderman, J. M. K., Gell, P. A., and Karoly, D. J.: Identifying coherent patterns of environmental change between multiple, multivariate records: an application to four 1000 year diatom records from Victoria, Australia, Quaternary Sci. Rev., 119, 94-105, https://doi.org/10.1016/j.quascirev.2015.04.010, 2015.

van der Kaars, S. and De Deckker, P.: A Late Quaternary pollen record from deep-sea core Fr10/95, GC17 offshore Cape Range Peninsula, northwestern Western Australia, Rev. Palaeobot. Palyno., 120, 17-39, https://doi.org/10.1016/s00346667(02)00075-1, 2002.

van Dijk, A., Beck, H. E., Crosbie, R. S., de Jeu, R. A. M., Liu, Y. Y., Podger, G. M., Timbal, B., and Viney, N. R.: The Millennium Drought in southeast Australia (2001-2009): natural and human causes and implications for water resources, ecosystems, economy, and society, Water Resour. Res., 49, 1040-1057, https://doi.org/10.1002/wrcr.20123, 2013.

van Ommen, T. D. and Morgan, V.: Snowfall increase in coastal East Antarctica linked with southwest Western Australian drought, Nat. Geosci., 3, 267-272, https://doi.org/10.1038/ngeo761, 2010.

Vandergoes, M. J., Dieffenbacher-Krall, A. C., Newnham, R. M., Denton, G. H., and Blaauw, M.: Cooling and changing seasonality in the Southern Alps, New Zealand during the Antarctic Cold Reversal, Quaternary Sci. Rev., 27, 589-601, https://doi.org/10.1016/j.quascirev.2007.11.015, 2008.

Villalba, R., Cook, E. R., Darrigo, R. D., Jacoby, G. C., Jones, P. D., Salinger, M. J., and Palmer, J.: Sea-level pressure variability around Antarctica since AD 1750 inferred from subantarctic tree-ring records, Clim. Dynam., 13, 375-390, https://doi.org/10.1007/s003820050172, 1997.

von Gunten, L., Grosjean, M., Kamenik, C., Fujak, M., and Urrutia, R.: Calibrating biogeochemical and physical climate proxies from non-varved lake sediments with meteorological data: methods and case studies, J. Paleolimnol., 47, 583-600, https://doi.org/10.1007/s10933-012-9582-9, 2012.

Walker, D., Head, M. J., Hancock, G. J., and Murray, A. S.: Establishing a chronology for the last 1000 years of laminated sediment accumulation at Lake Barrine, a tropical upland maar lake, northeastern Australia, Holocene, 10, 415-427, https://doi.org/10.1191/095968300671950228, 2000.

Whinam, J. and Hope, G.: The peatlands of the Australasian region, Stapfia, 85, 397-433, 2005.

Wigdahl, C. R., Saros, J. E., Fritz, S. C., Stone, J. R., and Engstrom, D. R.: The influence of basin morphometry on the regional coherence of patterns of diatom-inferred salinity in lakes of the northern Great Plains (USA), Holocene, 24, 603-613, https://doi.org/10.1177/0959683614523154, 2014.

Wilkins, D., De Deckker, P., Fifield, L. K., Gouramanis, C., and Olley, J.: Comparative optical and radiocarbon dating of laminated Holocene sediments in two maar lakes: Lake Keilambete and Lake Gnotuk, southwestern Victoria, Australia, Quat. Geochronol., 9, 3-15, https://doi.org/10.1016/j.quageo.2012.01.008, 2012.
Wilkins, D., De Deckker, P., Fifield, L. K., Gouramanis, C., and Olley, J.: Lake Keilambete, SE Australia Holocene sediment data and lake level, available at: https://www.ncdc.noaa.gov/paleo/ study/22430 (last access: 17 October 2017), 2013a.

Wilkins, D., Gouramanis, C., De Deckker, P., Fifield, L. K., and Olley, J.: Holocene lake-level fluctuations in Lakes Keilambete and Gnotuk, southwestern Victoria, Australia, Holocene, 23, 784795, https://doi.org/10.1177/0959683612471983, 2013b.

Williams, P. W., Neil, H. L., and Zhao, J. X.: Age frequency distribution and revised stable isotope curves for New Zealand speleothems: palaeoclimatic implications, Int. J. Speleol., 39, 99-112, 2010.

Wilmshurst, J. M., McGlone, M. S., and Partridge, T. R.: A late Holocene history of natural disturbance in lowland podocarp/hardwood forest, Hawke's Bay, New Zealand, New Zeal. J. Bot., 35, 79-96, 1997.

Wilmshurst, J. M., McGlone, M. S., and Charman, D. J.: Holocene vegetation and climate change in southern New Zealand: linkages between forest composition and quantitative surface moisture reconstructions from an ombrogenous bog, J. Quaternary Sci., 17, 653-666, https://doi.org/10.1002/jqs.689, 2002.

Wilmshurst, J. M., McGlone, M. S., Leathwick, J. R., and Newnham, R. M.: A pre-deforestation pollen-climate calibration model for New Zealand and quantitative temperature reconstructions for the past 18000 years BP, J. Quaternary Sci., 22, 535-547, https://doi.org/10.1002/jqs.1135, 2007.

Winder, M. and Schindler, D. E.: Climatic effects on the phenology of lake processes, Glob. Change Biol., 10, 1844-1856, https://doi.org/10.1111/j.1365-2486.2004.00849.x, 2004.

Woltering, M., Atahan, P., Grice, K., Heijnis, H., Taffs, K., and Dodson, J.: Glacial and Holocene terrestrial temperature variability in subtropical east Australia as inferred from branched GDGT distributions in a sediment core from Lake McKenzie, Quaternary Res., 82, 132-145, https://doi.org/10.1016/j.yqres.2014.02.005, 2014.

Woodward, C. A. and Shulmeister, J.: Chironomid-based reconstructions of summer air temperature from lake deposits in Lyndon Stream, New Zealand spanning the MIS 3/2 transition, Quaternary Sci. Rev., 26, 142-154, https://doi.org/10.1016/j.quascirev.2006.06.004, 2007.

Xia, Q., Zhao, J.-X., and Collerson, K. D.: Early-Mid Holocene climatic variations in Tasmania, Australia: multi-proxy records in a stalagmite from Lynds Cave, Earth Planet. Sc. Lett., 194, 177187, https://doi.org/10.1016/S0012-821X(01)00541-6, 2001.

Zachos, J. C., Stott, L. D., and Lohmann, K. C.: Evolution of early Cenozoic marine temperatures, Paleoceanography, 9, 353-387, https://doi.org/10.1029/93pa03266, 1994.

Zhang, X., Heijnis, H., Dodson, J., Zawadzki, A., and Buchanan, G.: Environmental changes indicated by grain-size and trace-metal analysis over the past 700 years at Annaburroo Billabong, NT, Australia, Quaternary Australasia, 28, 3-10, 2011.

Zhao, J. X., Yu, K. F., and Feng, Y. X.: High-precision U-238-U-234-Th-230 disequilibrium dating of the recent past: a review, Quat. Geochronol., 4, 423-433, https://doi.org/10.1016/j.quageo.2009.01.012, 2009. 